\title{
Ortaokul Öğrencilerinin Matematik Öğrenmelerinde Algılanan Ebeveyn Destek Düzeylerinin Bazı Değişkenler Açısından İncelenmesi
}

\section{Deniz Kaya ${ }^{1}$}

Type/Tür:

Research/Araştırma

Received/Geliş Tarihi: January

22/ 22 Ocak 2020

Accepted/Kabul Tarihi: March

4/4 Mart 2021

Page numbers/Sayfa No: $53-76$

Corresponding

Author/İletişimden Sorumlu

Yazar: denizkaya38@gmail.com

\section{$\checkmark$ iThenticate}

This paper was checked for plagiarism using iThenticate during the preview process and before publication. / Bu çalışma ön inceleme sürecinde ve yayımlanmadan önce iThenticate yazılımı ile taranmıştır.

\section{Copyright $@ 2017$ by}

Cumhuriyet University, Faculty of Education. All rights reserved.

\section{Öz}

Araştırma kapsamında ortaokul öğrencilerinin matematik öğrenmelerinde algılanan ebeveyn destek düzeyleri narsisizm, cinsiyet, matematik başarısı, kardeş sayısı, anne ve baba eğitim düzeyi açısından incelenmiştir. Araştırma şehir merkezindeki bir devlet ortaokulunun 6., 7. ve 8. sinıf düzeylerinde öğrenim gören toplam 544 öğrenci ile yürütülmüştür. Araştırmada veri toplama araçları olarak Algılanan Ebeveyn Desteği ile Çocukluk Çağı Narsisizm ölçekleri kullanılmıştır. İlişkisel tarama modelinin benimsendiği araştırmada, betimsel istatistiksel tekniklerin yanı sıra Pearson momentler çarpımı korelâsyon katsayısı, t-testi ve tek yönlü varyans analizleri (ANOVA) kullanılmıştır. Çalışmanın bulgularına göre, öğrencilerin matematik öğrenmelerinde algilanan ebeveyn desteği ile narsisizm düzeyleri ortalama değerin üzerinde bulunmuştur. Ortaokul öğrencilerinin matematik öğrenmelerinde algılanan ebeveyn desteği ile narsisizm arasında pozitif yönlü anlamlı ilişkiler bulunmuştur. Ayrıca ebeveyn teşviki ile matematik başarısı, kardeş sayısı ve baba eğitim düzeyi arasında; babanın tutumu ve yardımı ile sınıf düzeyi, kardeş sayısı, anne ve baba eğitim düzeyi arasında; annenin tutumu ve yardımı ile kardeş sayısı, anne ve baba eğitim düzeyi arasında anlamlı farklılıklar tespit edilmiştir. Öğrencilerin matematik öğrenmelerinde algılanan ebeveyn desteği ile cinsiyet değişkeni arasında anlamlı bir farklılık bulunmamıştır. Çalışma sonunda, ebeveynlerin çocuklarının kişilik özelliklerini ve gelişim düzeylerini dikkate alarak onlara yardımcı olmaları ve öğrenme çabalarını narsistik bir doyum sağlama aracına dönüştürmemeleri öneri olarak sunulmuştur.

Anahtar Kelimeler: Algilanan ebeveyn destek, cinsiyet, matematik, narsisizm, ortaokul

\section{Suggested APA Citation/Önerilen APA Atıf Biçimi:}

Kaya, D. (2021). Ortaokul öğrencilerinin matematik öğrenmelerinde algılanan ebeveyn destek düzeylerinin bazı değişkenler açısından incelenmesi. Cumhuriyet International Journal of Education, 10(1), 53-76. http://dx.doi.org/10.30703/cije.678911

\footnotetext{
1 Dr., Milli Eğitim Bakanlığı, İzmir/Türkiye

PhD., Ministry of National Education, İzmir/Turkey

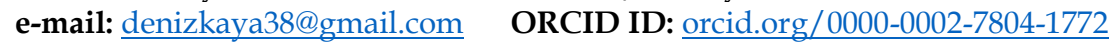




\title{
Investigation of Perceived Parental Support Levels on Middle School Students' Mathematics Learning in Terms of Some Variables
}

\begin{abstract}
Within the scope of the research, perceived parental support levels on middle school students' mathematics learning were examined in terms of narcissism, gender, mathematics success, number of siblings, and mother and father education level. The research was conducted with a total of 544 students studying at the $6^{\text {th }}, 7^{\text {th }}$, and $8^{\text {th }}$ gradelevels of a public middle school in the city center. Perceived Parental Support and Childhood Narcissism scales were used as data collection tools in the research. In addition to descriptive statistical techniques, Pearson product-moment correlation coefficient, t-test, and one-way analysis of variance (ANOVA) were used in the research, in which the relational scanning model was adopted. According to the findings of the study, the dimensions of perceived parental support levels on students' mathematics learning and narcissism level were found above-average value. Positive correlations were found between perceived parental support and narcissism on middle school students' mathematics learning. Also, significant differences were found between parent encouragement and mathematics success, number of siblings, and level of father education; between father's attitudes and help, and the level of the class, the number of siblings, and the education level of the mother and father; between mother's attitudes and help, and the number of siblings, and the education level of the mother and father. There was no significant difference between the perceived parental support on students' mathematics learning and gender variables. At the end of the study, it was suggested that parents take into account their children's personality traits and development levels and not turn their learning efforts into a narcissistic satisfaction tool.
\end{abstract}

Keywords: Perceived parental support, gender, mathematics, narcissism, middle school

\section{Giriş}

Geleceği şekillendirmede söz sahibi olacak yegâne varlığımız şüphesiz çocuklarımız olacaktır (MEB, 2018a). Sağlıklı bir toplum yapısını tasarlayacak çocuklarımızın iyi birer birey olarak yetişmeleri de tam bu noktada önem arz etmektedir. Çocuklarımızın sağlıklı bir kişilik yapısına sahip olması, kendisi ile uyumlu, çevresiyle barışık, yeterli bilgi ve becerilere sahip iyi birer teknoloji, fen ve matematik yeterlilikleri ile donanmış olmaları toplumların arzu ettiği bir durumdur (MEB, 2016; NRC, 2012). Özellikle teknolojinin yükselişine bağlı olarak 21. yüzyıl becerileri olarak anılan problem çözme, muhakeme etme, öz-yeterlik, eleştirel ve analitik düşünme gibi becerilerin öneminin giderek artması bu durumu daha da zorunlu kılmaktadır (NRC, 2012). Dolayısıyla çağın gereklerine uygun bilgi ve becerilere sahip nesillerin yetiştirilmesi ülkelerin sosyal, ekonomik ve kültürel ilerlemeleri açısından öncelikleri arasında yer almaktadır (MEB, 2016). Çünkü bilimsel faaliyetlerin katlanarak artması ve teknolojinin baş döndürücü hızı karşısında bireysel başarıyı artırmak toplumsal başarının ön koşulu olarak kabul edilmektedir (Eurydice, 2011). Bu doğrultuda, çok sayıdaki ülke eğitim politikalarının dinamiklerinde köklü değişikliklere giderek bireysel gelişimleri daha fazla dikkate alan bir dizi eğitim anlayışına kapı aralamıştır (NCTM, 2014). Ülkemiz eğitim sistemi de eğitim ihtiyaçlarını ve hedeflerini değiştirme konusunda güçlü adımlar atarak yetkinliklerle bütünleşmiş bilgi, beceri ve davranışlara sahip bireyler yetiştirme anlayışını eğitim felsefesinin odak noktası haline getirmiştir (MEB, 2018b). Tüm bu olumlu gelişmelere rağmen birçok ülke için öğrencilerin başarı seviyesi arzu edilenin oldukça altındadır (MEB, 2014, 2015, 2019; OECD, 2016; Provasnik vd., 2016; 
Schleicher, 2018). Oysa ülkelerin hedeflerini geliştirmeye/değiştirmeye yönlendirecek en önemli unsur sahip olduğu bireylerinin iyi birer öğrenen olmaları ile yakından ilgilidir. Bu öğrencilerin öğrenmeleri üzerinde etkili olan faktörlerin bilinmesi ve bu doğrultuda çalışmaların yürütülmesi oldukça değerlidir.

Öğrencilerin etkili birer öğrenen olmalarında çok sayıda faktör grubunun etkisinden söz etmekle birlikte okul iklimi, öğretmen, öğrenci ve aile temel etkenler arasında yer almaktadır (MEB, 2014). Okul türü ve okulun sahip olduğu kaynaklar başta olmak üzere öğretmen özellikleri ile aile desteği öğrencilerin öğrenmelerini ve başarılarını doğrudan etkilemektedir (Mullis vd., 2012). Özellikle ailelerin çocuklarına destek olmaları, uygun çalışma koşulları sunmaları, yardım ve rehberlik etmeleri ve onların gelişimlerini yakından takip etmeleri başarıyı olumlu yönde etkilemektedir (Lam ve Ducreux, 2013; Savaş, Taş ve Duru, 2010). Dolayısıyla ebeveyn desteğini etkili bir şekilde hisseden öğrencilerin öğrenmeleri olumlu yönde değişim göstermektedir (Desforges ve Abouchaar, 2003). Ayrıca ebeveynlerin eğitim ve öğretim faaliyetlerinin içinde yer almaları, çocuklarının performanslarıyla ilgili doğru inançlar ve beklentiler oluşturmaları davranışsal uyumların yanı sıra akademik başarıya da olumlu katkılar sunmaktadır (Alexander, Entwisle ve Bedinger, 1994; Berger, 1991; Davis-Kean, 2005; Kotaman, 2008; Lam ve Ducreux, 2013). Bu minvalde ebeveyn ilgisi ile öğrenci başarısı arasında güçlü bir bağın olduğu sıklıkla vurgulanmaktadır (Fan ve Chen, 2001; MEB, 2014, 2015). İlgili alanyazında, ebeveyn desteğinin öğrencilerin özellikle matematik başarıları ile matematiğe yönelik tutumları üzerinde önemli bir etkisinin olduğu öne sürülmektedir (Akyüz ve Pala, 2010; Cao, Bishop ve Forgasz, 2006; Ma, 2001; Özer ve An1l, 2011; Öztürk, 2016; Papanastasiou, 2000; Schleicher, 2018; Usta, 2014). Ebeveyn beklentisinin matematik başarısında güçlü bir etkisinin olduğunun anlaşılmasıyla birlikte çok sayıdaki çalışmada ebeveynlerin çocuklarının matematiksel öğrenmeleri üzerinde oynağı roller ele alınmıştır (Hunt ve Hu, 2011; Kleanthous ve Williams, 2013; Ma, 2001; Soni ve Kumari, 2015). Yapılan çalışmalarda ebeveynlerin motive edici ve destekleyici tutumlarının yanı sıra eğitim-öğretim sürecine katılımları da öğrencilerin matematik başarılarının önemli yordayıcıları olduğu belirtilmektedir (Cai, Moyer ve Wang, 1999; Cai, 2003; Cao vd., 2006; Hacısalihoğlu-Karadeniz, Aksu ve Topal, 2012). Nitekim öğrencilerin matematik başarılarının ve derse katılımlarının ebeveynlerinin tutum ve isteklerinden önemli ölçüde etkilendiği vurgulanmaktadır (Ma, 2001). Aynı zamanda ebeveynlerin hem dolaylı hem de dolaysız yardımlarının öğrencilerin sosyal yeterliliklerini, kavram öğrenmelerini, akademik motivasyonlarını, problem çözme becerilerini ve öğretmenleriyle olan ilişkilerini geliştirdiği belirlenmiştir (Cai vd., 1999; Cao vd., 2006; Hunt ve Hu, 2011; Johnson ve Descartes, 2016; Lam ve Ducreux, 2013; Ma, 2001; Régner, Loose ve Dumas, 2009; Sarıkaya, 2019; Yiğit, 2019). Bu doğrultuda, ebeveyn desteğinin/ilgisinin öğrenciyi birçok yönden olduğu gibi matematik başarısı yönünden de etkisi altına aldığı söylenebilir.

Ebeveyn etkisinin hissedildiği alanlardan birisi de narsisizmdir (Campbell ve Foster, 2007). Kısaca narsisizm, bireyin kendisine karşı duyduğu hayranlık ve bağlılık duygusu olarak tanımlanmaktadır (Gönülalan, 2019). Narsisizm kişinin kendisine yönelen ilgi ve eğilimi bir başka ifade ile kişilik özelliğidir (Levy, Ellison ve Reynoso, 2011). Narsisizmin gelişim sürecinde ebeveynlerin önemli etkileri bulunmaktadır. Öyle ki ebeveynlerin duygudaşlıktan yoksun tutumu, çocuklarını eşsiz görmeleri, onlara aşırı değer vermeleri ve mükemmellik beklentileri narsisizmin gelişmesinde 
önemli bir faktör olarak görülmektedir (Brummelman ve Gürel, 2019; Kohut, 1984; Özözen-Danac1, 2017). Narsist kişilik özelliklerine sahip bireylerin kendilerini diğer bireylerden üstün gördükleri, yüksek düzeyde bir beklenti içinde oldukları ve başarı doyumuna ihtiyaç duydukları bilinmektedir (Byrne ve Worthy, 2013; Kohut, 1984). Bu bakımdan sosyal değişimlerin psikolojik etkilerini anlamamız açısından narsisizm kavramı önemli bir yer edinmiştir (Battal, 2016). Narsisizm kavramı patolojik kişilik bozukluğunun ötesinde ailenin etkilerinin yoğun olarak hissedildiği, bireylerin sosyal çevredeki yalnızlığını ve güçsüzlüğünü konu edinen geniş bir yelpaze alanına sahiptir (Campbell ve Foster, 2007). Ailenin çocuklarını yetiştirme stilleri ile narsisizm arasında nedensel bir bağın olduğu belirtilmektedir (Akın, Şahin ve Gülşen, 2015). Bir çocuğun kişilik özelliklerini şekillendirme ve davranışlarını düzenleme rolü düşünüldüğünde aileden beklenen ilgi ve desteğin yönü oldukça önemli bir hal almaktadır (Gönülalan, 2019). Bu bakımdan yalnızca kişilik özellikleri bağlamında değil öğrenme sürecine dâhili de önemli bir çalışma alanını oluşturmaktadır. Nitekim bireylerdeki narsisizm düzeyi arttıkça geleneksel öğrenme-öğretme yaklaşımlarının daha çok benimsendiği bilinmektedir (Doruk, Bahçivan ve Yavuzalp, 2018). Bu bağlamda, çocukların bilişsel becerilerin gelişiminde algılanan ebeveyn etkisinin narsisizmle ilişkisi kaçınılmazdır. Özellikle öğrencilerin algılanan ebeveyn destekleri üzerindeki bu olgunun yönünün bilinmesi araştırmaya değer bir konu olarak karşımıza çıkmaktadır. Bu duruma dikkat çeken Peker'e (2015) göre, anne ve baba kabul ilgisi büyüklenmeci narsisizme, aşırı düzey denetim ve kontrolcü tutumun yanı sıra sevgi, kabul ve ilgi eksikliği de kırılgan narsisizme neden olmaktadır. Oysa sağlıklı narsisizm kişiliğine sahip olan bireylerde zorluklar karşısında mücadele etme ve amaçları doğrultusunda çaba harcama eğilimi daha fazla görülmektedir (Bolelli, 2018). Narsisizmin oluşumundaki ebeveyn etkileri dikkate alındığında öğrencilerin matematik öğrenmeleri üzerinde algılanan ebeveyn desteği ile narsisizm arasındaki ilişkinin bilinmesi oldukça önemli bir konudur. Çünkü ilgili literatürde çoğunlukla narsisizm; öz yeterlik, iş ve çalışma hayatı, benlik saygısı, yaşantı, mutluluk, okul, öğretmen ve aile değişkenleri bağlamında ele alınmaktadır (Battal, 2016; Bolelli, 2018; Brummelman, 2018; Campbell ve Foster, 2007; Doruk vd., 2018; Gönülalan, 2019; Karakuş, 2017; Özözen-Danac1, 2017; Peker, 2015; Rhodewalt ve Morf, 1998). Alanyazında ortaokul öğrencilerinin matematik öğrenmeleri üzerinde algılanan ebeveyn desteği ile narsisizmi konu edinen bir çalışmaya rastlanılmamış olması çalışmanın gerekliliğine vurgu yapmaktadır.

Alanyazın incelendiğinde, ebeveynlerin çocuklarının matematik öğrenmeleri üzerinde takip etme, motivasyon ve kaynak sağlama, içerik ve öğrenme danışmanı olmak üzere beş farklı rolünden bahsedilmektedir (Cai vd., 1999). Özellikle öğrencinin ebeveyn işlevselliği ile matematik başarısının, problem çözme becerisinin, iletişiminin ve uyumunun ilişkili olduğu sıklıkla dile getirilmektedir (Dubois, Eitel ve Felner, 1994; Eccles, Jacobs ve Harold, 1990; Erbay, 2013). Ailenin algilanan desteğinin öğrencilerin matematik başarılarını kaygı, özgüven, ilgi ve çaba aracılığı ile dolaylı olarak etkilediği belirtilmektedir (Öztürk, 2016). Aynı zamanda anne ve baba eğitim düzeyi arttıkça öğrencilerin hem matematik başarıları (Karabay, 2013; MEB, 2016; TEDMEM, 2014) hem de matematik okuryazarlık performanslarının arttığ belirtilmektedir (Akyüz ve Pala, 2010; Usta, 2014). Ancak ilgili alanyazında ebeveyn eğitim düzeyinin öğrencilerin matematik okuryazarlığı performanslarını manidar düzeyde yordadığı bulgulara da rastlanılmaktadır (MEB, 2015). Şentürk'e (2019) göre, eğitim durumu iyi olan ailelerin 
öğrencilerine derslerde yardımcı olması onların başarılarını da artırmaktadır. Eğitim durumu iyi olan ailedeki öğrencinin eksiklerini tamamladığı ve ailenin iyi bir rehber olması nedeniyle öğrenci özgüveninin daha yüksek düzeyde olduğu belirtilmiştir. Ailede yaşayan kişi sayısına göre geniş ailede yaşayan öğrencilerin çalışma ortamının olmayışı ve aile ilgisinin daha az olması sebebiyle çekirdek aileye göre daha düşük başarı gösterdikleri belirlenmiştir. Bunların yanı sıra babanın matematik tutumu erkek çocuklarının, annenin matematik tutumu da kız çocuklarının matematik başarılarına ve tutumlarına pozitif yönde etki ettiği çalışma sonuçları da bulunmaktadır (Soni ve Kumari, 2015). Diğer yandan öğrencilerin matematik başarıları üzerinde anne eğitim düzeyinin baba eğitim düzeyinden daha etkili olduğuna yönelik çalışma sonuçlarına da rastlanılmaktadır (Usta, 2014). Alanyazın genel olarak irdelendiğinde, anne ve baba eğitim düzeyinin artışına bağlı olarak öğrencilerin matematik performanslarında da artış olduğu gözlenmiştir (Dubois vd., 1994; Hunt ve Hu, 2011; Karaca, 2018; Özgen ve Bindak, 2011; Uysal ve Yenilmez, 2011). Bu duruma dikkat çeken Özer ve Anıl'a (2011) göre, ebeveynlerin eğitim düzeyi arttıkça aile özellikleri olumlu yönde etkilenmekte ve bu durumda öğrencinin akademik başarısına olumlu yansımaktadır. TIMSS, PISA ve PIRLS gibi uluslararası kuruluşların yapmış oldukları çalışmalar da ebeveynlerin eğitim durumu ile çocuklarının başarıları arasında güçlü bir bağın olduğuna işaret etmektedir (MEB, 2014; Mullis vd., 2012).

Sonuç olarak, aynı öğrenme ortamını paylaşan öğrenciler arasında matematik başarıları arasında farklılıkların olması öğrencilerin başarılarına etki eden faktörlerin araştırılmasını aynı zamanda başarıyı artırıcı koşulların neler olduğunun bilinmesini zorunlu kılmaktadır. İlgili alanyazında öğrencilerin matematik öğrenmeleri üzerinde algılanan ebeveyn desteğini konu edinen ve narsisizm, cinsiyet, matematik başarısı, kardeş sayısı, anne ve baba eğitim düzeyi gibi değişkenlerle birlikte ele alındığı kısıtlı sayıda çalışmaların bulunması yürütülen çalışmanın önemli gerekçeleri arasında yer almaktadır. Bu doğrultuda aşağıdaki alt problemlere yanıtlar aranmıştır:

1. Ortaokul öğrencilerinin algılanan ebeveyn desteği ile narsisizm düzeyleri ne seviyedir?

2. Ortaokul öğrencilerinin matematik öğrenmeleri üzerinde algilanan ebeveyn desteği ile narsisizm arasında bir ilişki var mıdır?

3. Ortaokul öğrencilerinin matematik öğrenmeleri üzerinde algılanan ebeveyn desteği cinsiyet, sınıf düzeyi, matematik başarısı, kardeş sayısı, anne ve baba eğitim düzeyi değişkenlerine göre anlamlı bir farklılık göstermekte midir?

\section{Araştırma Modeli}

\section{Yöntem}

Bu araştırmada, ortaokul öğrencilerinin matematik öğrenmelerinde algılanan ebeveyn desteği narsisizm, cinsiyet, sınıf düzeyi, matematik başarısı, kardeş sayısı, anne ve baba eğitim düzeylerine göre incelendiğinden ilişkisel tarama modeli tercih edilmiştir. Tarama modelleri, çok sayıda elemandan oluşan bir evrende evren hakkında genel bir yargıya varmak için örneklem üzerinde yapılan çalışmaları kapsamaktadır (Karasar, 2019, s. 111). İlişkisel tarama modeli ise iki ya da daha çok sayıdaki değişken arasında birlikte değişimin varlığını ve/veya derecesini belirlemeyi amaç edinmektir (Karasar, 2019, s. 114). 


\section{Çalışma Grubu}

Araştırmanın çalışma grubunu, 2019-2020 eğitim-öğretim yılında şehir merkezindeki bir devlet ortaokulunun 6., 7. ve 8. sinıflarında öğrenim görmekte olan toplam 544 öğrenci oluşturmaktadır. Gönüllü olarak çalışmada yer alan öğrencilerin 273'ü (\%50.2) k1z, 271'i (\%49.8) erkek öğrenciden oluşmaktadır. Çalışmaya toplamda 553 öğrenci katılmış ancak yedi öğrenci bilgi formunu eksik doldurduğundan, iki öğrencinin de yeni nakil gelmesinden kaynaklı matematik notu eksik olduğundan çalışmaya dâhil edilmemiştir. Çalışma grubunun belirlenmesinde seçkisiz olmayan uygun örnekleme yöntemi dikkate alınmış ve çalışmada farklı sınıf seviyelerinden öğrencilere de yer verilerek çalışmanın etki alanı genişletilmeye çalışılmıştır. Bu örnekleme yönteminde, araştırmacılar para ve işgücü kaybını önlemek için katılımcıları ulaşması kolay aynı zamanda araştırma için uygun aynı zamanda gönüllü bireylerden seçer (Büyüköztürk vd., 2019). Yaşları 10 ile 15 aralığında değişim gösteren öğrencilerin yaş ortalaması 12.2' dir. Öğrencilerin 181'i (\%33.3) altınc1, 181'i (\%33.3) yedinci ve 182'si (\%33.4) ise sekizinci sınıf düzeyinde öğrenim görmektedir. Bu öğrencilerin sınıf seviyesi, cinsiyet, kardeş sayısı, anne ve baba eğitim düzeyine ait bilgiler aşağıdaki tabloda sunulmuştur.

Tablo 1.

Çalışma Grubuna İlişkin Demografik Bilgiler

\begin{tabular}{|c|c|c|c|c|c|c|c|c|c|}
\hline \multirow{2}{*}{\multicolumn{2}{|c|}{ Değişkenler }} & \multicolumn{2}{|c|}{ 6. sinif } & \multicolumn{2}{|c|}{ 7. sinif } & \multicolumn{2}{|c|}{ 8. sinif } & \multicolumn{2}{|c|}{ Toplam } \\
\hline & & \multirow{2}{*}{$\begin{array}{l}\text { Frekans } \\
89\end{array}$} & \multirow{2}{*}{$\frac{\text { Yüzde }}{49.2}$} & Frekans & Yüzde & Frekans & Yüzde & \multicolumn{2}{|c|}{ Frekans Yüzde } \\
\hline Cinsiyet & $\mathrm{K}_{1 Z}$ & & & 95 & 52.5 & 89 & 48.9 & 273 & 50.2 \\
\hline & Erkek & 92 & 50.8 & 86 & 47.5 & 93 & 51.1 & 271 & 49.8 \\
\hline \multirow{5}{*}{ Kardeş Sayısı } & Kardeşi yok & 10 & 5.5 & 5 & 2.8 & 9 & 4.9 & 24 & 4.4 \\
\hline & 1 kardeş & 52 & 28.7 & 58 & 32.0 & 14 & 7.7 & 124 & 22.8 \\
\hline & 2 kardeş & 58 & 32.0 & 64 & 35.4 & 53 & 29.1 & 175 & 32.2 \\
\hline & 3 kardeş & 31 & 17.1 & 29 & 16.0 & 59 & 32.4 & 119 & 21.9 \\
\hline & 4 ve üzeri kardeş & 30 & 16.6 & 25 & 13.8 & 47 & 25.8 & 102 & 10.1 \\
\hline \multirow{5}{*}{$\begin{array}{l}\text { Anne Eğitim } \\
\text { Düzeyi }\end{array}$} & Okur-yazar değil & 24 & 13.3 & 32 & 17.7 & 34 & 18.7 & 90 & 16.5 \\
\hline & 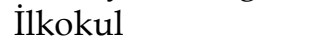 & 67 & 37.0 & 79 & 43.6 & 77 & 42.3 & 223 & 41.0 \\
\hline & Ortaokul & 61 & 33.7 & 41 & 22.7 & 40 & 22.0 & 142 & 26.1 \\
\hline & Lise & 21 & 11.6 & 17 & 14.9 & 29 & 15.9 & 77 & 14.2 \\
\hline & Üniversite ve üzeri & 8 & 4.4 & 2 & 1.1 & 2 & 1.1 & 12 & 2.2 \\
\hline \multirow{6}{*}{$\begin{array}{c}\text { Baba Eğitim } \\
\text { Düzeyi }\end{array}$} & Okur-yazar değil & 10 & 5.5 & 5 & 2.8 & 9 & 4.9 & 24 & 4.4 \\
\hline & İlkokul & 59 & 32.6 & 70 & 38.7 & 63 & 34.6 & 192 & 35.3 \\
\hline & Ortaokul & 64 & 35.4 & 61 & 33.7 & 56 & 30.8 & 181 & 33.3 \\
\hline & Lise & 33 & 18.2 & 32 & 17.7 & 39 & 21.4 & 104 & 19.1 \\
\hline & Üniversite ve üzeri & 15 & 8.3 & 13 & 7.2 & 15 & 8.2 & 43 & 7.9 \\
\hline & Toplam & 181 & 100 & 181 & 100 & 182 & 100 & 544 & 100 \\
\hline
\end{tabular}

\section{Veri Toplama Araçları}

Öğrencilerin matematik öğrenmeleri üzerinde algılanan ebeveyn desteğini belirlemek için Cao vd., (2006) tarafından geliştirilmiş olan Algılanan Ebeveyn Desteği ölçeği kullanılmıştır. Ebeveyn Teşviki boyutunda 6, Babanın Tutumu ve Yardımı boyutunda 4, Annenin Tutumu ve Yardımı boyutunda 4, Ebeveyn Başarı Beklentisi boyutunda 2 madde olmak üzere ölçek toplam dört boyuttan oluşmaktadır. Bu dört boyut sirasıyla toplam varyansın \%19.71, \%18.61, \%15.63 ve \%12.60'nı açılamaktadır. Geliştirilen ölçeğin hesaplanan Cronbach's alpha iç tutarlık katsayısı ise .87 olarak belirtilmiştir. 16 maddeden oluşan ölçeğin Türkçe uyarlaması araştırmacı tarafından yapılmış ve üç 
alan uzmanı ile bir dil bilimcisinden görüş ve yardım alınmıştır. 16 maddelik ölçeğin Cronbach's alpha iç tutarlık katsayısı test edilmiş ve .84 olarak bulunmuştur. Diğer yandan ölçeğe ait boyutların Cronbach's alpha iç tutarlık katsayıları da hesaplanmış ve sırasıyla; Ebeveyn Teşviki .80, Babanın Tutumu ve Yardımı .76, Annenin Tutumu ve Yardımı .68, Ebeveyn Başarı Beklentisi .76 olarak bulunmuştur. Genel bir kanı olarak güvenirlik katsayısı .70 ve üzerinde yer alan ölçeklerin güvenilir olduğu kabul edilmektedir (Fraenkel, Wallend ve Hyun, 2012) ancak madde sayısı az olan ölçekler için .60 üzerindeki güvenirlik katsayıları da ölçüt olarak kullanılabilmektedir (Şeker ve Gençdoğan, 2006). Bu doğrultuda, ölçme aracının ve boyutlarının beklenilen ölçüm güvenirliğine sahip olduğu söylenebilir. Ayrıca çalışma kapsamında ölçeğin yapı geçerliliği birinci düzey doğrulayıcı faktör analizi (DFA) ile test edilmiştir. Ölçekte yer verilen maddelerin basıklık değerlerinin .05 ile -1.74; çarpıklık değerlerinin .03 ile 2.56 arasında değiştiği gözlenmiştir. Buna göre, ölçekte yer alan hiçbir maddenin çarpıklık ve basıklık değerlerinin \pm 3 sınırları dışında kalmadı̆̆ı söylenebilir (Kline, 2005). Ayrıca parametre tahminin standart hataya bölünmesi ile elde edilen kritik oran (critical ratio) değerleri de .05 anlamlılık düzeyinde tüm maddeler için anlamlı bulunmuştur (Khine, 2013). Aynı zamanda ölçeği oluşturan boyutların da veri setiyle yeterli uyum içinde olduğu belirlenmiştir $\left(\chi^{2} / \mathrm{sd}=2.06, \mathrm{RMSEA}=.08, \mathrm{NNFI}=.93, \mathrm{RFI}=.90, \mathrm{CFI}=.90, \mathrm{GFI}=.96\right.$, AGFI=.86). Buna göre, modele ilişkin uyum değerleri; modelin kabul edilebilir ve mükemmel uyumlara sahip olduğuna işaret etmektedir (Hu ve Bentler, 1999; Kline, 2005). Ölçekte yer alan ifadeler için tamamen katılıyorum (4), katılıyorum (3), katılmıyorum (2) ve tamamen katılmıyorum (1) şeklinde Likert tipi bir derecelendirme kullanılmıştır. Ölçeğe ait örnek maddeler aşağıda sunulmuştur:

1. Annemin matematik bilgisi iyidir.

2. Babam bazı zor matematik problemlerinde bana yardım eder.

Ortaokul öğrencilerinin narsisizm düzeylerini belirlemek için Akın, Şahin ve Gülşen (2015) tarafından güvenirliği ve geçerliği test edilerek Türkçeye uyarlanmış Çocukluk Çağı Narsisizm ölçeği tercih edilmiştir. Ölçeğin orijinal formu Thomaes, Stegge, Bushman, Olthof ve Denissen (2008) tarafından geliştirmiştir. Ölçek tek boyut ve 10 maddeden oluşmaktadır. Ölçekte; hiç doğru değil (0), çok da doğru değil (1), oldukça doğru (2) ve kesinlikle doğru (3) şeklinde Likert tipi bir derecelendirme tercih edilmiştir. Ölçeğin temel yaklaşımlarından birisi çocukluk çağı narsisizmini kişilik bozukluğu olarak değil, kişilik özelliği olarak ölçebilmektir. Ölç̧me aracının orijinal formu için belirlenen Cronbach's alpha iç tutarlılık katsayıs1 .84, faktör yükleri ise .53 ile .74 aralığı olarak belirtilmiştir. Türkçeye uyarlanan formunda ise iç tutarlılık katsayısı .72 olarak bulunmuş ve ölçeğin yeterli uyum indekslerine sahip olduğu belirtilmiştir $\left(\chi^{2}=49.88\right.$, $\mathrm{sd}=35, p=.04$, RMSEA=.04, NFI=.91, $\mathrm{IFI}=.97, \mathrm{CFI}=.97, \mathrm{GFI}=.96$, SRMR=.05). Çalışma kapsamında da ölçeğin Cronbach's alpha iç tutarlılık katsayısı test edilmiş .71 olarak bulunmuştur. Ölçekte yer alan maddelerin basıklık değerlerinin -.62 ile -1.19; çarpıklık değerlerinin ise .01 ile .63 arasında değiştiği belirlenmiştir. Bu bulgulara göre, ölçekteki maddelerin çarpıklık ve basıklık değerleri \pm 3 sınırları içerisinde yer almaktadır (Kline, 2005). Ölçeğe ait örnek maddeler aşağıda sunulmuştur:

1. Çok özel bir insanım.

2. Sınıfımızda ben olmazsam sınıfımız daha az eğlenceli olurdu.

3. Ben diğer çocuklar için mükemmel örneğim. 
Araştırmada öğrencilerin cinsiyet, sınıf, kardeş sayısı, anne ve baba eğitim düzeylerinin tespiti için kişisel bilgi formu kullanılmıştır. Bu kapsamda, öğrenciler kendilerine uygun seçeneği işaretleyerek bilgi formunu doldurmuştur. Diğer yandan öğrencilerin matematik başarılarını belirlemek için dönem sonu matematik notları kullanılmıştır. Öğrencilerin dönem sonu matematik notları bir önceki öğrenim yılına ait matematik not ortalamalarından oluşmaktadır. Öğrencilerin matematik notlarının sınıflandırılmasında Milli Eğitim Bakanlığı İlköğretim Kurumları Yönetmeliğinde daha önceden yer verilmiş olan puan değerleri dikkate alınmıştır. Yönetmeliğe göre, 0-44 arası başarısız, 45-54 arası geçer, 55-69 arası orta, 70-84 arası iyi, 85-100 arası pekiyi olarak belirtilmiştir (www.meb.gov.tr/mevzuat/). Veri setini oluşturan ölçme araçları gerekli izinler alındıktan sonra araştırmacı tarafından uygulanmıştır.

\section{Verilerin Analizi}

Verilerin analizine geçmeden önce veri setinin her bir değişkene göre, ortalaması, standart sapması ve standart hata değerleri hesaplanmıştır. Daha sonra parametrik veya parametrik olmayan testlerden hangisinin kullanılacağına karar vermek için verilerin normallik analizleri yapılmıştır. Veri setinde yer alan değişkenlerin normal dağılama sahip olduğu belirlenmiştir. Bunların yanı sıra tek yönlü varyans analizinin gerçekleştirilebilmesi için gerekli varsayımlarından birisi olan varyansların eşitliğinin sınandığı Levene test sonuçlarına göre grupların aralarında anlamlı bir fark $(p>0.05)$ olmadığı belirlenmiştir. Bu bağlamda, bağımsız iki grup ortalaması için t-testi, ikiden fazla grup ortalaması için tek yönlü varyans analizi (ANOVA), değişkenler arasındaki doğrusal ilişki için Pearson momentler çarpımı korelâsyon katsayısı kullanılmıştır. Bu doğrultuda, korelasyon 0 ile \pm 0.29 arasında ise düşük, \pm 0.30 ile \pm 0.59 arasında ise orta ve \pm 0.60 ile \pm 1 arasında ise yüksek düzey ilişki olarak yorumlanmıştır (Büyüköztürk, 2011). Ayrıca çalışma kapsamında algılanan ebeveyn desteği ile narsisizm arasındaki ilişkilerin determinasyon katsayıları $\left(\mathrm{r}^{2}\right)$ da hesaplanmıştır. Determinasyon katsayısı $\left(\mathrm{r}^{2}\right)$ değişkenlerden birinde gözlenen değişkenliğin ne kadarının diğer bir değişken tarafından açıklandığını yorumlamada kullanılır, korelâsyon katsayısının (r) karesine eşittir (Büyüköztürk, 2011). Veri analizlerinde SPSS 22.0, DFA analizinde ise AMOS 24.0 programları kullanılmıştır.

\section{Bulgular}

Bu bölümde araştırmanın amacı doğrultusunda öncelikle değişkenlere ait betimsel değerler, sonrasında öğrencilerin matematik öğrenmeleri üzerinde algilanan ebeveyn desteği ile narsisizm, cinsiyet, sınıf düzeyi matematik başarısı, kardeş sayısı, anne ve baba eğitim düzeyi arasındaki ilişkiler sırasıyla ele alınmıştır.

Tablo 2 incelendiğinde, öğrencilerin matematik öğrenmelerinde ebeveyn teşviki boyutunda sekizinci sınıf $(\bar{X}=3.39)$ öğrencilerinin en yüksek ortalamaya sahip olduğu görülmektedir. Babanın tutumu ve yardımı $(\bar{X}=2.99)$, ananenin tutumu ve yardımı $(\bar{X}=2.78)$ ile ebeveyn başarı beklentisi $(\bar{X}=3.55)$ boyutlarında ise altıncı sınıf öğrencileri en yüksek ortalamaya sahiptir. Diğer yandan narsisizmde en yüksek ortalama yedinci sınıf $(\bar{X}=1.68)$ öğrencilerinde görülmektedir. 
Tablo 2.

Algılanan Ebeveyn Desteği ile Narsisizm Düzeylerine İlişkin Tanımlayıcı İstatistiksel Değerler

\begin{tabular}{cccccccc}
\hline Değişkenler & Sınıf Düzeyi & $N$ & $\bar{X}$ & Standart Sapma & Standart Hata & Minimum Maksimum \\
\hline Ebeveyn & 6 & 181 & 3.32 & 0.61 & 0.04 & 1.50 & 4.00 \\
Teşviki & 7 & 181 & 3.33 & 0.66 & 0.04 & 1.00 & 4.00 \\
& 8 & 182 & 3.39 & 0.55 & 0.04 & 1.50 & 4.00 \\
\hline Babanın Tutumu & 6 & 181 & 2.99 & 0.75 & 0.05 & 1.00 & 4.00 \\
ve Yardımı & 7 & 181 & 2.80 & 0.76 & 0.05 & 1.00 & 4.00 \\
& 8 & 182 & 2.67 & 0.78 & 0.05 & 1.00 & 4.00 \\
\hline Annenin Tutumu & 6 & 181 & 2.78 & 0.77 & 0.05 & 1.00 & 4.00 \\
ve Yardımı & 7 & 181 & 2.66 & 0.71 & 0.05 & 1.00 & 4.00 \\
& 8 & 182 & 2.60 & 0.64 & 0.04 & 1.00 & 4.00 \\
\hline Ebeveyn Başarı & 6 & 181 & 3.55 & 0.70 & 0.05 & 1.00 & 4.00 \\
Beklentisi & 7 & 181 & 3.51 & 0.72 & 0.05 & 1.00 & 4.00 \\
& 8 & 182 & 3.41 & 0.72 & 0.05 & 1.00 & 4.00 \\
\hline & 6 & 181 & 1.55 & 0.48 & 0.03 & 0.30 & 3.00 \\
Narsisizm & 7 & 181 & 1.68 & 0.51 & 0.03 & 0.20 & 2.90 \\
& 8 & 182 & 1.48 & 0.52 & 0.03 & 0.10 & 2.90 \\
\hline
\end{tabular}

Tablo 3'e göre, öğrencilerin matematik öğrenmelerinde ebeveyn teşviki ( $\mathrm{r}=.18$; $p<.05)$, babanın tutumu ve yardımı $(\mathrm{r}=.18 ; p<.05)$, annenin tutumu ve yardımı $(\mathrm{r}=.16$; $p<.05)$, ebeveyn başarı beklentisi $(\mathrm{r}=.16 ; p<.05)$ ile narsisizm düzeyleri arasında düşük düzeyde pozitif yönlü anlamlı ilişkiler olduğu görülmektedir. Diğer yandan bu iki değişkenden birisinin diğeri üzerinde ne derece etkili olduğunu belirlemek için determinsayon katsayıları hesaplanmıştır. Bu katsayılar dikkate alındığında, ebeveyn teşviki ile babanın tutumu ve yardımında $\% 3\left(\mathrm{r}^{2}=0.03\right)$, annenin tutumu ve yardımı ile ebeveyn başarı beklentisinde $\% 2\left(\mathrm{r}^{2}=0.02\right)$ oranında narsisizmin etkisi görülmektedir.

Tablo 3.

Algılanan Ebeveyn Desteği ile Narsisizm Arasındaki İlişki

\begin{tabular}{|c|c|c|c|c|c|c|}
\hline Değişkenler & & $\begin{array}{c}\text { Ebeveyn } \\
\text { Teşviki }\end{array}$ & $\begin{array}{c}\text { Babanın Tutumu } \\
\text { ve Yardımı }\end{array}$ & $\begin{array}{c}\text { Annenin Tutumu } \\
\text { ve Yardımı }\end{array}$ & $\begin{array}{c}\text { Ebeveyn Başar1 } \\
\text { Beklentisi }\end{array}$ & $\begin{array}{l}\text { Narsisizm } \\
\text { Düzeyi }\end{array}$ \\
\hline \multirow[t]{2}{*}{ Ebeveyn Teşviki } & $\mathrm{r}$ & 1 & .50 & .45 & .58 & .18 \\
\hline & $p$ & 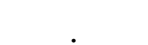 & $.00^{*}$ & $.00^{*}$ & $.00^{*}$ & $.00^{*}$ \\
\hline \multirow{2}{*}{$\begin{array}{c}\text { Babanın Tutumu } \\
\text { ve Yardımı }\end{array}$} & $\mathrm{r}$ & & 1 & .45 & .35 & .18 \\
\hline & $p$ & & . & $.00^{*}$ & $.00^{*}$ & $.00^{*}$ \\
\hline \multirow{2}{*}{$\begin{array}{c}\text { Annenin Tutumu } \\
\text { ve Yardımı }\end{array}$} & $\mathrm{r}$ & & & 1 & .29 & .16 \\
\hline & $p$ & & & . & $.00^{*}$ & $.00^{*}$ \\
\hline Ebeveyn Başarı & $\mathrm{r}$ & & & & 1 & .16 \\
\hline Beklentisi & $p$ & & & & . & $.00^{*}$ \\
\hline \multirow[t]{2}{*}{ Narsisizm } & $\mathrm{r}$ & & & & & 1 \\
\hline & $p$ & & & & & . \\
\hline
\end{tabular}


Tablo 4.

Cinsiyet Değgişkenine Göre Algılanan Ebeveyn Desteği t-Testi Sonuçları

\begin{tabular}{lccccccc}
\hline \multicolumn{1}{c}{ Değişkenler } & Cinsiyet & $N$ & $\bar{X}$ & $\mathrm{Ss}$ & $\mathrm{Sd}$ & $\mathrm{t}$ & $p$ \\
\hline Ebeveyn Teşviki & Kız & 273 & 3.38 & 0.58 & 542 & 1.11 & 0.26 \\
& Erkek & 271 & 3.32 & 0.64 & & & \\
Babanın Tutumu ve Yardımı & $\mathrm{K} ı \mathrm{z}$ & 273 & 2.83 & 0.77 & 542 & 0.23 & 0.81 \\
& Erkek & 271 & 2.81 & 0.78 & & & \\
Annenin Tutumu ve Yardımı & Kız & 273 & 2.65 & 0.71 & 542 & -1.01 & 0.31 \\
& Erkek & 271 & 2.71 & 0.71 & & & \\
Ebeveyn Başarı Beklentisi & Kız & 273 & 3.52 & 0.70 & 542 & 1.07 & 0.28 \\
& Erkek & 271 & 3.46 & 0.73 & & & \\
\hline
\end{tabular}

Tablo 4 incelendiğinde, öğrencilerin matematik öğrenmelerinde ebeveyn teşviki $(p>.05)$, babanın tutumu ve yardımı ( $p>.05)$, annenin tutumu ve yardımı ( $p>.05)$, ebeveyn başarı beklentisi $(p>.05)$ ile cinsiyet değişkeni arasında anlamlı bir farklılık bulunmamıştır.

Tablo 5.

Sınıf Düzeylerine Göre Algılanan Ebeveyn Desteği ANOVA Sonuçlarn

\begin{tabular}{|c|c|c|c|c|c|c|c|c|c|c|}
\hline Değişkenler & Sinif & $N$ & $\bar{X}$ & Ss & $\begin{array}{c}\text { Varyansın } \\
\text { Kaynağ1 }\end{array}$ & $\begin{array}{c}\text { Kareler } \\
\text { Toplamı }\end{array}$ & $\mathrm{Sd}$ & $\begin{array}{c}\text { Kareler } \\
\text { Ortalaması }\end{array}$ & $\mathrm{F}$ & $p$ \\
\hline \multirow{3}{*}{$\begin{array}{c}\text { Ebeveyn } \\
\text { Teşviki }\end{array}$} & 6 & 181 & 3.32 & 0.61 & Gruplar arası & 0.53 & 2 & 0.26 & 0.70 & 0.49 \\
\hline & 7 & 181 & 3.33 & 0.66 & Gruplar içi & 205.93 & 541 & 0.38 & & \\
\hline & 8 & 182 & 3.39 & 0.55 & Toplam & 206.47 & 543 & & & \\
\hline \multirow{3}{*}{$\begin{array}{l}\text { Babanın } \\
\text { Tutumu ve } \\
\text { Yardımı }\end{array}$} & 6 & 181 & 2.99 & 0.75 & Gruplar arası & 9.64 & 2 & 4.82 & 8.14 & $0.00^{*}$ \\
\hline & 7 & 181 & 2.80 & 0.76 & Gruplar içi & 320.06 & 541 & 0.59 & & \\
\hline & 8 & 182 & 2.67 & 0.78 & Toplam & 329.70 & 543 & & & \\
\hline \multirow{3}{*}{$\begin{array}{l}\text { Annenin } \\
\text { Tutumu ve } \\
\text { Yardımı }\end{array}$} & 6 & 181 & 2.78 & 0.77 & Gruplar arası & 2.73 & 2 & 1.36 & 2.67 & 0.07 \\
\hline & 7 & 181 & 2.66 & 0.71 & Gruplar içi & 275.89 & 541 & 0.51 & & \\
\hline & 8 & 182 & 2.60 & 0.64 & Toplam & 278.62 & 543 & & & \\
\hline \multirow{3}{*}{$\begin{array}{l}\text { Ebeveyn } \\
\text { Başarı } \\
\text { Beklentisi }\end{array}$} & 6 & 181 & 3.55 & 0.70 & Gruplar arası & 1.75 & 2 & 0.87 & 1.69 & 0.18 \\
\hline & 7 & 181 & 3.51 & 0.72 & Gruplar içi & 279.73 & 541 & 0.51 & & \\
\hline & 8 & 182 & 3.41 & 0.72 & Toplam & 281.48 & 543 & & & \\
\hline
\end{tabular}
${ }^{*} p<.05$

Tablo 5'e göre, öğrencilerin matematik öğrenmelerinde babanın tutumu ve yardımı ile sınıf düzeyleri arasında anlamlı bir farklılık olduğu görülmektedir $\left(\mathrm{F}_{(2,541)}=8.14 ; p<.05\right)$. Anlamlı farkın kaynağ1 LSD testine göre, altınc1 sınıfta eğitim gören öğrencilerinin yedinci ve sekizinci sinıflarda eğitim gören öğrencilerinin baba tutumu ve yardımı puan ortalamalarından daha fazladır. Benzer şekilde, yedinci sınıf öğrencileri ile sekizinci sınıf öğrencilerinin baba tutumu ve yardımı puan ortalamaları arasında anlamlı bir farklılık olduğu ve bu farklılığın puan ortalamasına göre yedinci sınıf öğrencileri lehine olduğu belirlenmiştir. Diğer yandan öğrencilerin matematik öğrenmeleri üzerinde ebeveyn teşviki $\left(\mathrm{F}_{(2,541)}=0.70 ; p>.05\right)$, annenin tutumu ve yardımı $\left(\mathrm{F}_{(2,541)}=2.67 ; p>.05\right)$, ebeveyn başarı beklentisi $\left(\mathrm{F}_{(2,541)}=1.69 ; p>.05\right)$ ile sınıf düzeyi değişkeni arasında anlamlı bir farklılık olmadığı belirlenmiştir.

Tablo 6 incelendiğinde, öğrencilerin matematik öğrenmelerinde ebeveyn teşviki ile matematik başarıları arasında anlamlı bir farklılık olduğu görülmektedir 
$\left(\mathrm{F}_{(4,539)}=3.81 ; p<.05\right)$. Bu anlamlı farkın kaynağ $\mathrm{LSD}$ testine göre, öğrencilerin başarıları arttıkça ebeveyn teşvik puan ortalamalarının da arttı̆̆ına işaret etmektedir. Buna göre, ebeveyn teşvikinin artışına bağlı olarak öğrencilerin matematik başarılarının da arttığı söylenebilir. Diğer yandan öğrencilerin matematik öğrenmelerinde babanın tutumu ve yardımı $\left(\mathrm{F}_{(4,539)}=0.28 ; p>.05\right)$, annenin tutumu ve yardımı $\left(\mathrm{F}_{(4,539)}=2.01 ; p>.05\right)$, ebeveyn başarı beklentisi $\left(\mathrm{F}_{(4,539)}=1.60 ; p>.05\right)$ ile matematik başarısı değişkeni arasında anlamlı bir farklılık olmadığı belirlenmiştir.

Tablo 6.

Matematik Başan Notuna Göre Algılanan Ebeveyn Desteği ANOVA Sonuçlan

\begin{tabular}{|c|c|c|c|c|c|c|c|c|c|c|}
\hline Değişkenler & Not & $N$ & $\bar{X}$ & Ss & $\begin{array}{l}\text { Varyansın } \\
\text { Kaynağı }\end{array}$ & $\begin{array}{c}\text { Kareler } \\
\text { Toplamı }\end{array}$ & $\mathrm{Sd}$ & $\begin{array}{c}\text { Kareler } \\
\text { Ortalamas1 }\end{array}$ & $\mathrm{F}$ & $p$ \\
\hline \multirow{5}{*}{$\begin{array}{l}\text { Ebeveyn } \\
\text { Teşviki }\end{array}$} & $0-44$ & 39 & 3.17 & 0.78 & Gruplar arası & 5.67 & 4 & 1.41 & 3.81 & $0.00^{*}$ \\
\hline & $45-54$ & 164 & 3.23 & 0.67 & Gruplar içi & 200.79 & 539 & 0.37 & & \\
\hline & $55-69$ & 167 & 3.40 & 0.56 & Toplam & 206.47 & 543 & & & \\
\hline & $70-84$ & 97 & 3.42 & 0.53 & & & & & & \\
\hline & $85-100$ & 77 & 3.47 & 0.54 & & & & & & \\
\hline \multirow{5}{*}{$\begin{array}{l}\text { Babanın } \\
\text { Tutumu ve } \\
\text { Yardımı }\end{array}$} & $0-44$ & 39 & 2.72 & 0.87 & Gruplar arası & 0.68 & 4 & 0.17 & 0.28 & 0.89 \\
\hline & $45-54$ & 164 & 2.84 & 0.73 & Gruplar içi & 329.02 & 539 & 0.61 & & \\
\hline & $55-69$ & 167 & 2.80 & 0.78 & Toplam & 329.70 & 543 & & & \\
\hline & $70-84$ & 97 & 2.86 & 0.81 & & & & & & \\
\hline & $85-100$ & 77 & 2.83 & 0.76 & & & & & & \\
\hline \multirow{5}{*}{$\begin{array}{l}\text { Annenin } \\
\text { Tutumu ve } \\
\text { Yardımı }\end{array}$} & $0-44$ & 39 & 2.40 & 0.75 & Gruplar arası & 4.11 & 4 & 1.02 & 2.01 & 0.09 \\
\hline & $45-54$ & 164 & 2.65 & 0.72 & Gruplar içi & 274.51 & 539 & 0.50 & & \\
\hline & $55-69$ & 167 & 2.75 & 0.74 & Toplam & 278.62 & 543 & & & \\
\hline & $70-84$ & 97 & 2.71 & 0.65 & & & & & & \\
\hline & $85-100$ & 77 & 2.69 & 0.67 & & & & & & \\
\hline \multirow{5}{*}{$\begin{array}{l}\text { Ebeveyn } \\
\text { Başarı } \\
\text { Beklentisi }\end{array}$} & $0-44$ & 39 & 3.28 & 0.81 & Gruplar arası & 3.31 & 4 & 0.82 & 1.60 & 0.17 \\
\hline & $45-54$ & 164 & 3.45 & 0.75 & Gruplar içi & 278.17 & 539 & 0.51 & & \\
\hline & $55-69$ & 167 & 3.49 & 0.70 & Toplam & 281.48 & 543 & & & \\
\hline & $70-84$ & 97 & 3.58 & 0.66 & & & & & & \\
\hline & $85-100$ & 77 & 3.57 & 0.68 & & & & & & \\
\hline
\end{tabular}

Tablo 7'ye göre, öğrencilerin matematik öğrenmelerinde ebeveyn teşviki $\left(\mathrm{F}_{(4,539)}=6.59 ; p<.05\right)$, babanın tutumu ve yardımı $\left(\mathrm{F}_{(4,539)}=6.01 ; p<.05\right)$, annenin tutumu ve yardımı $\left(\mathrm{F}_{(4,539)}=14.49 ; p<.05\right)$ ile kardeş sayıları arasında anlamlı bir farklılık olduğu görülmektedir. Anlamlı farkın kaynağı LSD testine göre, kardeş sayısı arttıkça ebeveyn teşviki, baba ile annenin tutumu ve yardımı puan ortalaması da azalmaktadır. Buna göre kardeş sayısı azaldıkça ebeveyn teşviki, baba ile annenin tutumu ve yardımı puan ortalaması da artmaktadır. Diğer yandan öğrencilerin matematik öğrenmeleri üzerinde ebeveyn başarı beklentisi ile kardeş sayısı değişkeni arasında anlamlı bir farklılık olmadığı belirlenmiştir $\left(\mathrm{F}_{(4,539)}=2.02 ; p>.05\right)$. 
Tablo 7.

Kardeş Sayısına Göre Algılanan Ebeveyn Desteği ANOVA Sonuçları

\begin{tabular}{|c|c|c|c|c|c|c|c|c|c|c|}
\hline Değişkenler & Kardeş Sayısı & $N$ & $\bar{X}$ & Ss & $\begin{array}{c}\text { Varyansın } \\
\text { Kaynağı }\end{array}$ & $\begin{array}{l}\text { Kareler } \\
\text { Toplamı }\end{array}$ & Sd & $\begin{array}{c}\text { Kareler } \\
\text { Ortalaması }\end{array}$ & $\mathrm{F}$ & $p$ \\
\hline \multirow{5}{*}{$\begin{array}{l}\text { Ebeveyn } \\
\text { Teşviki }\end{array}$} & 1 kardeş & 124 & 3.41 & 0.62 & Gruplar arası & 9.63 & 4 & 2.40 & 6.59 & $0.00^{*}$ \\
\hline & 2 kardeş & 175 & 3.48 & 0.54 & Gruplar içi & 196.83 & 539 & 0.36 & & \\
\hline & 3 kardeş & 119 & 3.26 & 0.64 & Toplam & 206.47 & 543 & & & \\
\hline & 4 ve üzeri kardeş & 102 & 3.13 & 0.64 & & & & & & \\
\hline & Hiç kardeşi yok & 24 & 3.40 & 0.55 & & & & & & \\
\hline \multirow{5}{*}{$\begin{array}{l}\text { Babanın } \\
\text { Tutumu ve } \\
\text { Yardımı }\end{array}$} & 1 kardeş & 124 & 2.88 & 0.78 & Gruplar arası & 14.06 & 4 & 3.51 & 6.01 & $0.00^{*}$ \\
\hline & 2 kardeş & 175 & 2.99 & 0.72 & Gruplar içi & 315.64 & 539 & 0.58 & & \\
\hline & 3 kardeş & 119 & 2.76 & 0.79 & Toplam & 329.70 & 543 & & & \\
\hline & 4 ve üzeri kardeş & 102 & 2.53 & 0.74 & & & & & & \\
\hline & Hiç kardeşi yok & 24 & 2.84 & 0.86 & & & & & & \\
\hline \multirow{5}{*}{$\begin{array}{l}\text { Annenin } \\
\text { Tutumu ve } \\
\text { Yardımı }\end{array}$} & 1 kardeş & 124 & 2.81 & 0.73 & Gruplar arası & 27.06 & 4 & 6.76 & 14.49 & $0.00^{*}$ \\
\hline & 2 kardeş & 175 & 2.88 & 0.67 & Gruplar içi & 251.55 & 539 & 0.46 & & \\
\hline & 3 kardeş & 119 & 2.60 & 0.68 & Toplam & 278.62 & 543 & & & \\
\hline & 4 ve üzeri kardeş & 102 & 2.26 & 0.60 & & & & & & \\
\hline & Hiç kardeşi yok & 24 & 2.77 & 0.78 & & & & & & \\
\hline \multirow{5}{*}{$\begin{array}{l}\text { Ebeveyn } \\
\text { Başarı } \\
\text { Beklentisi }\end{array}$} & 1 kardeş & 124 & 3.49 & 0.75 & Gruplar arası & 4.16 & 4 & 1.04 & 2.02 & 0.09 \\
\hline & 2 kardeş & 175 & 3.58 & 0.66 & Gruplar içi & 277.31 & 539 & 0.51 & & \\
\hline & 3 kardeş & 119 & 3.41 & 0.77 & Toplam & 281.48 & 543 & & & \\
\hline & 4 ve üzeri kardeş & 102 & 3.38 & 0.69 & & & & & & \\
\hline & Hiç kardeşi yok & 24 & 3.68 & 0.56 & & & & & & \\
\hline
\end{tabular}

Tablo 8 incelendiğinde, öğrencilerin matematik öğrenmelerinde baba tutumu ve yardımı $\left(\mathrm{F}_{(4,539)}=2.55 ; p<.05\right)$, anne tutumu ve yardım $\left(\mathrm{F}_{(4,539)}=27.09 ; p<.05\right)$ ile annenin eğitim düzeyi arasında anlamlı bir farklılık olduğu görülmektedir. Bu anlamlı farkın kaynağı LSD testine göre, annenin eğitim düzeyi arttıkça babanın tutumu ve yardımı ile annenin tutumu ve yardımı puan ortalamasının arttığına işaret etmektedir. Diğer yandan öğrencilerin matematik öğrenmelerinde ebeveyn teşviki $\left(\mathrm{F}_{(4,539)}=1.62\right.$; $p>.05)$, ebeveyn başarı beklentisi $\left(\mathrm{F}_{(4,539)}=2.03 ; p>.05\right)$ ile anne eğitim düzeyi değişkeni arasında anlamlı bir farklılık olmadığı belirlenmiştir.

Tablo 8.

Anne Eğitim Düzeyine Göre Algllanan Ebeveyn Desteği ANOVA Sonuçları

\begin{tabular}{|c|c|c|c|c|c|c|c|c|c|c|}
\hline Değişkenler & Eğitim Düzeyi & $\mathrm{N}$ & $\bar{X}$ & Ss & $\begin{array}{l}\text { Varyansın } \\
\text { Kaynağ1 }\end{array}$ & $\begin{array}{l}\text { Kareler } \\
\text { Toplamı }\end{array}$ & $\mathrm{Sd}$ & $\begin{array}{c}\text { Kareler } \\
\text { Ortalamas1 }\end{array}$ & $\mathrm{F}$ & $p$ \\
\hline \multirow{5}{*}{$\begin{array}{l}\text { Ebeveyn } \\
\text { Teşviki }\end{array}$} & Okuryazar değil & 90 & 3.30 & 0.62 & Gruplar arası & 2.46 & 4 & 0.61 & 1.62 & 0.16 \\
\hline & ílkokul & 223 & 3.30 & 0.64 & Gruplar içi & 204.01 & 539 & 0.37 & & \\
\hline & Ortaokul & 142 & 3.40 & 0.57 & Toplam & 206.47 & 543 & & & \\
\hline & Lise & 77 & 3.47 & 0.56 & & & & & & \\
\hline & $\begin{array}{c}\text { Üniversite ve } \\
\text { üzeri }\end{array}$ & 12 & 3.23 & 0.73 & & & & & & \\
\hline \multirow{4}{*}{$\begin{array}{l}\text { Babanın } \\
\text { Tutumu ve } \\
\text { Yardımı }\end{array}$} & Okuryazar değil & 90 & 2.68 & 0.79 & Gruplar arası & 6.12 & 4 & 1.53 & 2.55 & $0.03^{*}$ \\
\hline & İlkokul & 223 & 2.77 & 0.76 & Gruplar içi & 323.58 & 539 & 0.60 & & \\
\hline & Ortaokul & 142 & 2.96 & 0.71 & Toplam & 329.70 & 543 & & & \\
\hline & Lise & 77 & 2.91 & 0.85 & & & & & & \\
\hline
\end{tabular}




\begin{tabular}{|c|c|c|c|c|c|c|c|c|c|}
\hline & $\begin{array}{c}\text { Üniversite ve } \\
\text { üzeri }\end{array}$ & 12 & 2.60 & 0.88 & & & & & \\
\hline \multirow{5}{*}{$\begin{array}{l}\text { Annenin } \\
\text { Tutumu ve } \\
\text { Yardımı }\end{array}$} & Okuryazar değil & 90 & 2.24 & 0.65 & Gruplar arası & 46.63 & 4 & 11.65 & \multirow[t]{5}{*}{$27.090 .00^{*}$} \\
\hline & İlkokul & 223 & 2.54 & 0.70 & Gruplar içi & 231.98 & 539 & 0.43 & \\
\hline & Ortaokul & 142 & 2.93 & 0.61 & \multirow{3}{*}{ Toplam } & 278.62 & \multirow[t]{3}{*}{543} & & \\
\hline & Lise & 77 & 3.13 & 0.56 & & & & & \\
\hline & $\begin{array}{c}\text { Üniversite ve } \\
\text { üzeri }\end{array}$ & 12 & 2.83 & 0.80 & & & & & \\
\hline \multirow{5}{*}{$\begin{array}{l}\text { Ebeveyn } \\
\text { Başarı } \\
\text { Beklentisi }\end{array}$} & Okuryazar değil & 90 & 3.58 & 0.69 & Gruplar arası & 4.18 & 4 & 1.04 & \multirow[t]{5}{*}{$2.03 \quad 0.08$} \\
\hline & İlkokul & 223 & 3.40 & 0.76 & \multirow{4}{*}{$\begin{array}{l}\text { Gruplar içi } \\
\text { Toplam }\end{array}$} & 277.29 & 539 & 0.51 & \\
\hline & Ortaokul & 142 & 3.59 & 0.64 & & 281.48 & 543 & & \\
\hline & Lise & 77 & 3.44 & 0.75 & & & & & \\
\hline & $\begin{array}{c}\text { Üniversite ve } \\
\text { üzeri }\end{array}$ & 12 & 3.54 & 0.58 & & & & & \\
\hline
\end{tabular}

Tablo 9.

Baba Eğitim Düzeyine Göre Algulanan Ebeveyn Desteği ANOVA Sonuçlar

\begin{tabular}{|c|c|c|c|c|c|c|c|c|c|c|}
\hline Değişkenler & Eğitim Düzeyi & $N$ & $\bar{X}$ & Ss & $\begin{array}{c}\text { Varyansın } \\
\text { Kaynağ1 }\end{array}$ & $\begin{array}{c}\text { Kareler } \\
\text { Toplamı }\end{array}$ & $\mathrm{Sd}$ & $\begin{array}{c}\text { Kareler } \\
\text { Ortalaması }\end{array}$ & F & $p$ \\
\hline \multirow{5}{*}{$\begin{array}{l}\text { Ebeveyn } \\
\text { Teşviki }\end{array}$} & Okuryazar değil & 24 & 2.92 & 0.77 & Gruplar arası & 16.15 & 4 & 1.53 & 4.14 & $0.00^{*}$ \\
\hline & İlkokul & 192 & 3.31 & 0.61 & Gruplar içi & 200.31 & 539 & 0.37 & & \\
\hline & Ortaokul & 181 & 3.38 & 0.56 & Toplam & 206.46 & 543 & & & \\
\hline & Lise & 104 & 3.46 & 0.58 & & & & & & \\
\hline & $\begin{array}{c}\text { Üniversite ve } \\
\text { üzeri }\end{array}$ & 43 & 3.36 & 0.69 & & & & & & \\
\hline \multirow{5}{*}{$\begin{array}{l}\text { Babanın } \\
\text { Tutumu ve } \\
\text { Yardımı }\end{array}$} & Okuryazar değil & 24 & 2.50 & 0.81 & Gruplar arası & $\begin{array}{ll}1 & 19.30\end{array}$ & 4 & 4.82 & 8.37 & $0.00^{*}$ \\
\hline & İlkokul & 192 & 2.66 & 0.71 & Gruplar içi & 310.40 & 539 & 0.57 & & \\
\hline & Ortaokul & 181 & 2.81 & 0.79 & Toplam & & 543 & & & \\
\hline & Lise & 104 & 3.05 & 0.77 & & & & & & \\
\hline & $\begin{array}{c}\text { Üniversite ve } \\
\text { üzeri }\end{array}$ & 43 & 3.20 & 0.73 & & & & & & \\
\hline \multirow{5}{*}{$\begin{array}{l}\text { Annenin } \\
\text { Tutumu ve } \\
\text { Yardımı }\end{array}$} & Okuryazar değil & 24 & 2.47 & 0.75 & Gruplar arası & $\begin{array}{ll}1 & 4.90\end{array}$ & 4 & 1.22 & 2.41 & $0.04^{*}$ \\
\hline & İlkokul & 192 & 2.58 & 0.69 & Gruplar içi & 273.71 & 539 & 0.50 & & \\
\hline & Ortaokul & 181 & 2.74 & 0.67 & Toplam & 278.62 & 543 & & & \\
\hline & Lise & 104 & 2.79 & 0.80 & & & & & & \\
\hline & $\begin{array}{c}\text { Üniversite ve } \\
\text { üzeri }\end{array}$ & 43 & 2.73 & 0.66 & & & & & & \\
\hline \multirow{5}{*}{$\begin{array}{l}\text { Ebeveyn } \\
\text { Başarı } \\
\text { Beklentisi }\end{array}$} & Okuryazar değil & 24 & 3.25 & 0.98 & Gruplar arası & $1 \quad 2.76$ & 4 & 0.69 & 1.33 & 0.25 \\
\hline & İlkokul & 192 & 3.44 & 0.74 & Gruplar içi & 278.72 & 539 & 0.51 & & \\
\hline & Ortaokul & 181 & 3.54 & 0.66 & Toplam & 281.48 & 543 & & & \\
\hline & Lise & 104 & 3.54 & 0.69 & & & & & & \\
\hline & $\begin{array}{c}\text { Üniversite ve } \\
\text { üzeri }\end{array}$ & 43 & 3.51 & 0.68 & & & & & & \\
\hline
\end{tabular}

Tablo 9'a göre, öğrencilerin matematik öğrenmelerinde ebeveyn teşviki $\left(\mathrm{F}_{(4,539)}=4.14 ; p<.05\right)$, baba tutumu ve yardımı $\left(\mathrm{F}_{(4,539)}=8.37 ; p<.05\right)$, anne tutumu ve yardımı $\left(\mathrm{F}_{(4,539)}=2.41 ; p<.05\right)$ ile baba eğitim düzeyi arasında anlamlı bir farklılık olduğu görülmektedir. Bu anlamlı farkın kaynağ1 LSD testine göre, babanın eğitim düzeyi arttıkça ebeveyn teşviki, babanın tutumu ve yardımı ile annenin tutumu ve 
yardımı puan ortalaması da artmaktadır. Diğer yandan öğrencilerin matematik öğrenmeleri üzerinde ebeveyn başarı beklentisi $\left(\mathrm{F}_{(4,539)}=1.33 ; p>.05\right)$ ile baba eğitim düzeyi değişkeni arasında anlamlı bir farklılık olmadığı belirlenmiştir.

\section{Tartışma, Sonuç ve Öneriler}

$\mathrm{Bu}$ çalışmada, ortaokul öğrencilerinin matematik öğrenmelerinde algilanan ebeveyn desteği narsisizm, cinsiyet, sınıf düzeyi, matematik başarısı, kardeş sayısı, anne ve baba eğitim düzeyleri açısından incelenmiştir. Elde edilen betimsel bulgulara göre, ebeveyn teşviki boyutunda sekizinci sınıf, babanın tutum ve yardımı, annenin tutum ve yardımı ile ebeveyn başarı beklentisi boyutlarında altıncı sınıf öğrencilerinin ortalaması daha fazla bulunmuştur. Narsisizmde ise en yüksek ortalama yedinci sınıf öğrencilerinden elde edilmiştir. Öğrencilerin matematik öğrenmelerinde algılanan ebeveyn desteğinin tüm boyutları ile narsisizm düzeylerine ait değerler ortalamanın üzerinde bulunmuştur. Bu bulgulara göre, öğrencilerin matematik öğrenmelerinde algılanan ebeveyn desteğinin yönünün daha çok ortaokul eğitiminin ilk yıllarında yoğunlaştığ1 söylenebilir. Elde edilen bulgular, özellikle ortaokulun ilk dönemlerinde ebeveynler çocuklarının eğitimlerine daha fazla ilgi duyarlar ve onları destekler söylemiyle örtüşmektedir (Cai, 2003; Johnson ve Descartes, 2016). Oysa ebeveynlerin öğrenme üzerindeki rolü çocuk farklı öğrenme kademelerinde eğitimini sürdürdükçe de devam etmektedir. Çocuğun eğitim hayatı boyunca ailelerin sorumluluklarının azalmadığı bilinmektedir (Sarıkaya, 2019). Bundan dolayı ebeveynlerin çocuklarının matematik öğrenmelerindeki görevlerini yerine getirirken desteklerinin sürdürülebilir olması oldukça önemlidir. Diğer yandan narsisizm düzeyinin en yüksek ortalamaya sahip olduğu yaş grubu ise ergenlik döneminin yoğun olarak hissedildiği döneme denk gelmektedir. Narsisizmin tanımına da vurgu yapan bu durum öğrencilerin kişilik özelliğinin bir yansımasıdır (Levy vd., 2011). Nitekim ebeveynlerin çocuklarını yetiştirirken sergiledikleri tutumlar çocuklarının kişiliklerini de etkilemektedir (Lam ve Ducreux, 2013). Bundan dolayı ebeveynlerin çocuklarının gelişim düzeylerini ve kişilik özelliklerini dikkate alarak onlara rehberlik etmeleri ve öğrenmelerine yardımcı olmaları oldukça önemlidir.

Araştırmanın diğer bulgusu, ortaokul öğrencilerinin matematik öğrenmeleri üzerinde algılanan ebeveyn desteği ile narsisizm arasındaki ilişkiden elde edilmiştir. Elde edilen bulgular, öğrencilerin matematik öğrenmeleri üzerinde ebeveyn teşviki, babanın tutumu ve yardımı, annenin tutumu ve yardımı, ebeveyn başarı beklentisi ile narsisizm düzeyleri arasında pozitif yönde anlamlı ilişkiler olduğunu göstermektedir. Bu bulgular, bireylerdeki narsisizmin oluşmasında temel faktörler arasında gösterilen ebeveynlerin etkilerini doğrulamaktadır (Brummelman ve Gürel, 2019; Campbell ve Foster, 2007; Rhodewalt ve Morf, 1998). Ayrica elde edilen bu bulgular, ebeveynlerin çocuklarının kişilik özelliklerini etkilemesinin yanı sıra çocuklarının öğrenmeleri üzerinde de narsisizm olgusuna neden olabileceğini göstermektedir. Ebeveynlerin çocukları ile olan etkileşimlerinde benimsedikleri tutumlar, çocuğun kişiliğinin yanı sıra bilişsel gelişiminde de önemli bir rol üstlendiği birçok yaklaşım içinde kabul görmüştür (Kohut, 1984). Dolayısıyla ebeveynlerin çocuklarının etkili birer matematik öğrenenleri olmalarında sahip olduğu uygun sorumluluklar ile destekleyici tutumları oldukça değerlidir. Çünkü günlük hayatta karşılaşılan bir dizi problemi çözmek için uygun matematiksel düşünme tarzının geliştirilmesi ve uygulanması gerekir (MEB, 2018b). Bireylerin bu ihtiyaçlarının karşılanmasında yetersiz düzeyde kalınması, öz 
saygıyı düzenleyen zihinsel yapıların gerilemesine aynı zamanda gerçeklik ilkesinden uzaklaşmasına neden olacağ gibi matematik öğrenmeye yönelik narsistik bir gelişimi de tetikleyecektir (Kohut, 1984). Bu bakımdan, ebeveynlerin çocuğun kendine özgü özelliklerini algılama, kabul etme ve destekleme konusunda uygun davranışlar sergilemesi ve matematik öğrenme çabalarını narsistik bir doyum sağlama aracına dönüştürmemesi gerekir. Aksi halde çocuklarının matematik öğrenmeleri üzerinde kırılgan narsisizme yani endişeli, ürkek ve güvensiz özellikler göstermelerine neden olurlar. Ebeveyn ile çocuk arasındaki kurulan ilişkinin kalitesi çocuğun sağlıklı bir matematik öğrenen olması açısından gereklidir. Ebeveynin çocuğu yetiştirme stilinin ihtiyaç ve beklentilere cevap verecek nitelik taşıması yalnızca sağlıklı bir psikolojik gelişim açısından değil iyi bir öğrenen olması açısından da önemlidir (Bolelli, 2018). Dolayısıyla gerek ebeveynlerin gerekse matematik öğretmenlerinin çocukların kişilik özelliklerini iyi bilmesi, onların içsel deneyimlerine ve kişisel ihtiyaçlarına empati ile yaklaşması gerekir. Ebeveynler, çocuklarının matematik öğrenmeleri üzerinde narsist bir etki bırakmamak için çocuklarının çabalarına değer vermeli onların özgüvensiz refleksler göstermelerinin önüne geçmelidir. Özellikle anne ve babalar çocuklarının matematik gayretlerinin farkında olmalı ve çocuklarının matematiksel gelişimlerine uygun davranışlar sergilemelidir. Nitekim ebeveynin olumlu tutumu çocuğun sağlıklı bir benlik yapısı oluşturmasına dolayısıyla kendine güvenen bir birey olmasına olanak sağlamaktadır (Battal, 2016; Brummelman ve Gürel, 2019; Fan ve Chen, 2001). Bundan dolayı gelişiminde ebeveynlerin etkisinin olduğu açıkça bilinen narsisizm konusunda ebeveynlerin daha eğitimli ve bilinçli olmaları gerekir.

Araştırmadan elde edilen diğer bulguda, öğrencilerin matematik öğrenmeleri üzerinde algılanan ebeveyn desteğinin cinsiyete göre farklılık göstermediği tespit edilmiştir. Buna göre, algılanan ebeveyn etkisinin çocuklarının matematik öğrenmeleri üzerinde cinsiyet ayrımı gözetmediği söylenebilir. Nitekim ebeveynlerin öğrencilerin eğitime katılımının önemi tartışmaya açık olmayan bir durum olmakla birlikte etkili ebeveyn rolleri günümüzde hala cevap aranan bir soru olarak karşımıza çıkmaktadır (Cai vd., 1999). Ebeveynler çocuklara sunduğu öğrenme desteğinde cinsiyet ayrımına yapmamalarına rağmen kız ve erkek çocuklarının matematik öğrenmelerine yönelik farklı bir tutum veya bakış açısı içerisinde olabilmektedir. Nitekim bu yönde ilgili alanyazında güçlü bulgulara rastlamak mümkündür. Örneğin Eccles vd., (1990) göre, altıncı sınıfa kadar ebeveynler erkek öğrencilerin matematikte daha doğal yeteneklere sahip olduğuna inanmakta ve matematiğin öneminin erkek öğrenciler için kızlardan fazla olduğunu değerlendirmektedir. Bu yüzden erkek çocuk ebeveynleri çocuklarının daha yüksek matematiğe sahip olduğuna yönelik inanma eğilimi taşımaktadır. Benzer bir diğer örnekte ise babanın matematik tutumunun erkek çocuklarının matematik tutumuna ve başarısına kız çocuklarından daha fazla etki ettiği belirtilmektedir (Soni ve Kumari, 2015). Bu düşüncelerden hareketle, ebeveynlerin çocuklarının matematik öğrenmelerinde daha duyarlı hareket etmeleri ve onların gayretlerini desteklemeleri önerilmektedir.

Araştırmadan elde edilen bir diğer bulgu, sınıf düzeylerine göre öğrencilerin matematik öğrenmelerinde algılanan ebeveyn desteğinden elde edilmiştir. Bulgulara göre, algılanan ebeveyn desteği içerisinden babanın tutumu ve yardımı alt sınıf düzeyi lehine anlamlılık göstermektedir. Bu bulgulara göre, babanın çocuklarının matematik öğrenmeleri üzerindeki etkisi sınıf düzeylerine göre diğer ebeveyn desteklerinden 
daha fazla hissedilmektedir. Elde edilen bu sonuç, alanyazında dile getirilen babanın algılanan matematik tutumu çocuklarının matematik tutumu ve başarılarına pozitif yönde etki etmektedir bulgularını da desteklemektedir (Soni ve Kumari, 2015). Ancak alanyazında çocuklarının matematik öğrenmeleri üzerinde annelerin etkililiğinin daha yoğun olarak hissedildiği araştırma bulguları da bulunmaktadır (Hunt ve $\mathrm{Hu}, 2011$ ). Çalışmanın bulguları özellikle erken yaş grubundaki çocuklar üzerindeki algılanan baba tutum ve yardımının çocukların matematik öğrenmeleri üzerinde olumlu etkiler bıraktığını göstermektedir. İlgili alanyazında ailenin çocukla ilişkilerinin dolayısıyla ebeveyn tutumunun öğrenci başarısındaki önemi sıklıkla vurgulanmaktadır (Cai, 2003; Davis-Kean, 2005; Desforges ve Abouchaar, 2003; Fan ve Chen, 2001; Hunt ve $\mathrm{Hu}, 2011)$. Bu bakımdan küçük yaşlardan itibaren gerek babaların gerekse annelerin çocuklarının matematik öğrenmeleri üzerindeki güdülerini harekete geçirmesi ve onlara iyi bir rol model olması gerekir. Bir çocuğun öğrenme davranışlarını etkileyen en önemli faktör ailedir. Çocuğun ebeveyn ile arasındaki ilişkileri onların derslere yönelik bakış açılarını da şekillendirir. Ebeveynlerin çocuklarının matematiksel bilgi ve becerilerini desteklemesi ilerleyen yıllarda matematiği daha kolay algılamalarına katkı sağlar. Bu yüzden ebeveynlerin çocuklarının öğrenme isteklerine değer vermesi ve onları dinlemesi oldukça değerlidir. Ebeveynler hangi öğrenme kademesi ya da yaş aralığında olursa olsun çocuklarının matematik öğrenmelerine yardımcı ayrıca destek olmaları gerekir. Bu sayede çocuğun okulda edinmiş olduğu matematiksel becerilerin daha iyi içselleştirmelerine de kapı aralamış olurlar.

Araştırmanın diğer bulgusu ise öğrencilerin matematik başarılarında ebeveyn teşvikinin anlamlı bulunmasıdır. Buna göre, öğrencilerin matematik başarılarının yükselmesinde ebeveyn teşvikinin önemli bir yer edindiği söylenebilir. Nitekim bu bulgu, alanyazında sıklıkla dile getirilen ve birçok çalışma sonucu ile doğrulanan ebeveyn teşviki ve gayretlerinin çocuklarının matematik başarılarında önemli bir etkendir söylemlerini de desteklemektedir (Cai vd., 1999; Cao vd., 2006; Erbay, 2013; Hunt ve Hu, 2011; Kleanthous ve Williams, 2013; Ma, 2001; Soni ve Kumari, 2015). Uluslararası çalışma kuruluşların belirli aralıklarla yayınlamış olduğu raporlarda da öğrencilerin matematik başarılarında ebeveynlerin önemli bir etkisi olduğu sıklıkla vurgulanmaktadır (MEB, 2019; Mullis vd., 2012). Bu yüzden ebeveynler çocuklarının iyi birer matematiksel düşünme becerisine sahip olmalarında oldukça kritik görevler üstlenmektedir. Çünkü ebeveynlerin ve ailelerin çocuklarının ilk eğitimcisi oldukları, çocuklarının öğrenme ve gelişimlerinin sosyal ve entelektüel temellerini atmaktan sorumlu kişiler oldukları yaygın bir kanı olarak kabul edilmektedir (Cai, 2003; Eccles vd., 1990). Bu bakımdan öğrencilerin matematik öğrenmeleri üzerinde ebeveynlerin yadsınamaz etkisinin olumlu sonuçlanmasında ebeveynlerin kendi sorumluluklarının farkında olması ve çocuklarıyla iyi ilişkiler geliştirmesi son derece önemlidir.

Araştırmadan elde edilen diğer bulgularda, kardeş sayısı artıkça öğrencilerin matematik öğrenmelerinde algılanan ebeveyn teşviki, babanın tutum ve yardımı ile annenin tutum ve yardımının azaldığ belirlenmiştir. Bu durumun birçok temel sebebi olmakla birlikte en önemli nedenler arasında ebeveynlerin çocuklarına yönelik ilgisiz tutumları yer almaktadır (Şentürk, 2019). Bundan dolayı ebeveynlerin çocuklarının matematik öğrenmelerine yardımcı olurken dengeli bir tutum içinde olmaları aynı zamanda matematik öğrenme görevlerinde çocuklarını cesaretlendirmeleri önemlidir. Aksi halde ebeveynlerin çocuklarına yönelik reddedici tutumları onların matematik 
öğrenmeleri üzerinde olumsuz bir etki oluşturabilir. Araştırmanın bir diğer adımında ise öğrencilerin matematik öğrenmelerinde baba tutumu ve yardımı, anne tutumu ve yardımı ile annenin eğitim düzeyi arasında; ebeveyn teşviki, baba tutumu ve yardımı, anne tutumu ve yardımı ile baba eğitim düzeyi arasında anlamlı farklılıklar olduğu tespit edilmiştir. Buna göre, annenin ve babanın eğitim düzeyi artıkça öğrencilerin matematik öğrenmelerinde algılanan ebeveyn etkisinin de arttığı belirlenmiştir. Bu bulgular, benzer çalışma sonuçları ile paralellik göstermektedir (Cai, 2003; Karaca, 2018; MEB, 2015; Özgen ve Bindak, 2011; Şentürk, 2019; Uysal ve Yenilmez, 2011). Nitekim anne ve baba eğitim düzeyinin çocuğun başarısında anahtar bir rol üstlendiği birçok çalışma ile doğrulanmıştır (MEB, 2014; Mullis vd., 2012). Ancak TIMSS 2011 verilerine göre, anne ve babasından en az birisinin üniversite ya da daha üst düzeyde eğitim alma durumu açısından ülkemizin karnesi oldukça kötü durumdadır (MEB, 2014). Dolayısıyla ülkemizdeki ebeveynlerin öğrenme düzeylerinin artırılması ya da ebeveynlerin çocuklarının öğrenme gelişimleri üzerindeki farkındalıklarını artıracak faaliyetlere ağırlık verilmesi son derece önem arz etmektedir.

Sonuç olarak, çocuklarımızın iyi bir matematik öğreneni olmalarında ebeveyn desteği yadsınamaz bir öneme sahiptir. Bu yüzden çocukların öğrenme süreçlerinde tüm paydaşların üzerine düşün sorumluklarının farkında olması ve yerine getirmesi gerekir. Nitekim algılanan ebeveyn desteğinin devamlılı̆̆ını sağlanmak amacıyla ebeveynlerin eğitilmesi de çocuklarımızın eğitilmesi kadar gerekli ve bir o kadar da önemlidir. Ebeveynlerin gerekli bilgi ve becerilere sahip olması sadece çocuğunu değil tüm toplumu da yakından ilgilendirmektedir. Bundan dolayı ebeveynlerin öğrenme üzerindeki etkisini konu edinen çalışmalara daha fazla ağırlık verilmesi gerekir. Tüm bu anlatımlara ek olarak, çalışmanın bazı sınırlılıkları da bulunmaktadır. Örneğin öğrencilerin matematik başarısını etkileyecek faktör gruplarını azaltmak için elde edilen veriler tek bir kurumla sınırlı tutulmuştur. Benzer bir çalışma farklı yerleşim birimlerinde ya da sosyo-ekonomik düzey açısından farklı kurumlarda yürütülebilir. Çalışmanın diğer sınırlılı̆̆ı ise çalışmada gönüllü öğrencilere yer verilmiş olmasıdır. Çalışmada yer almak istemeyen öğrencilerin matematik öğrenmelerindeki algılanan ebeveyn desteğinin yönü farklılık gösterebilir. Dolayısıyla bu öğrencilerin matematik öğrenmelerindeki algılanan ebeveyn desteğinin birtakım değişkenlerle olan ilişkisinin bilinmesi de önemlidir.

\section{Kaynakça}

Akın, A., Şahin, M. ve Gülşen, M. (2015). Çocukluk çağı narsisizm ölçeği: Geçerlik ve güvenirlik çalışması. Dicle Üniversitesi Ziya Gökalp Eğitim Fakültesi Dergisi, 24, 203-215. https://doi.org/10.14582/DUZGEF.759.

Akyüz, G. ve Pala, N. M. (2010). PISA 2003 sonuçlarına göre öğrenci ve sınıf özelliklerinin matematik okuryazarlığına ve problem çözme becerilerine etkisi. İlköğretim Online, 9(2), 668-678.

Alexander, K. L., Entwisle, D. R., and Bedinger, S. D. (1994). When expectations work: Race and socioeconomic differences in school performance. Social Psychology Quarterly, 57(4), 283-299. https://doi.org/10.2307/2787156.

Battal, F. B. (2016). Narsistik kişilik yapılanmasının aile ve çocuk bağlamında incelenmesi. (Yayımlanmamış yüksek lisans tezi). Necmettin Erbakan Üniversitesi, Konya.

Berger, E. H. (1991). Parent involvement: Yesterday and today. The Elementary School Journal, 91(3), 209-219. 
Bolelli, M. (2018). Narsistik kişilik özelliklerinin işe bağlılı̆̆a etkileri: Örnek bir araştırma. Gazi İktisat ve Işletme Dergisi (Gazi Journal of Economics \& Business), 4(3), 185-199. https:/ / doi.org/10.30855/gjeb.2018.4.3.005.

Brummelman, E. (2018). The emergence of narcissism and self-esteem: A socialcognitive approach. European Journal of Developmental Psychology, 15(6), 756767. https:/ / doi.org/10.1080/17405629.2017.1419953.

Brummelman, E., and Gürel, Ç. (2019). Childhood narcissism. A call for interventions. Journal of Affective Disorders, 244, 113-114.

https:// doi.org/10.1016/j.jad.2018.10.101.

Büyüköztürk, Ş., Çakmak, E. K., Akgün, Ö. E., Karadeniz, Ş. ve Demirel, F. (2019). Eğitimde bilimsel araştırma yöntemleri (26. Bask1). Ankara: Pegem Akademi.

Büyüköztürk, Ş. (2011). Sosyal bilimler için veri analizi el kitabı (15.Baskı). Ankara: Pegem Akademi.

Byrne, K. A., and Worthy, D. A. (2013). Do narcissists make better decisions? An investigation of narcissism and dynamic decision-making performance. Personality and Individual Differences, 55(2), 112-117. https:// doi.org/10.1016/j.paid.2013.02.020.

Cai, J., Moyer, J. C., and Wang, N. (1999). Parental roles in students' learning of mathematics: An exploratory study. Research in Middle Level Education Quarterly, 22(3), 1-18. https:/ / doi.org/10.1080/10848959.1999.11670147.

Cai, J. (2003). Investigating parental roles in students' learning of mathematics from a cross-national perspective. Mathematics Education Research Journal, 15(2), 87106. https:/ / doi.org/10.1007/BF03217372.

Campbell, K. W., and Foster, J. D. (2007). The narcissistic self: Background, an extended agency model, and ongoing controversies. In Sedikides, C., \& Spencer, S. (Eds.). The self (pp. 115-138). New York: Psychology Press.

Cao, Z., Bishop, A., and Forgasz, H. (2006). Perceived parental influence on mathematics learning: A comparison among students in China and Australia. Educational Studies in Mathematics 64(1), 85-106. https:// doi.org/10.1007/s10649-006-9033-5.

Davis-Kean, P. E. (2005). The influence of parent education and family income on child achievement: The indirect role of parental expectations and the home environment. Journal of Family Psychology, 19(2), 294-304. https:// doi.org/10.1037/0893-3200.19.2.294.

Desforges, C., and A. Abouchaar (2003). The impact of parental involvement, parental support and family education on pupil achievements and adjustment: A literature review. Research Report 433. London: Department for Education and Skills.

Doruk, B. K., Bahçivan, E. ve Yavuzalp, N. (2018). Öğretmen adaylarının benlik saygıları, narsisizm düzeyleri ve öğrenme-öğretme yaklaşımları arasındaki ilişki üzerine bir inceleme. Turkish Journal of Educational Studies, 5(3), 118-139. https:// doi.org/10.33907/turkjes.468591.

Dubois, D. L., Eitel, S. K., and Felner, R. D. (1994). Effects of family environment and parent-child relationships on school adjustment during the transition to early adolescence. Journal of Marriage and the Family, 56(2), 405-414.

https:// doi.org/10.2307/353108. 
Eccles, J. S., Jacobs, J. E., and Harold, R. D. (1990). Gender role stereotypes, expectancy effects, and parents'socialization of gender differences. Journal of Social Issues, 46(2), 183-201. https:// doi.org/10.1111/j.1540-4560.1990.tb01929.x.

Erbay, H. N. (2013). Aile işlevselliğinin matematik başarısıyla ilişkisi. Güney Kore-Türkiye karşılaştırılması. (Yayımlanmamış yüksek lisans tezi). Marmara Üniversitesi, İstanbul.

Eurydice, E. P. (2011). Mathematics education in Europe: Common challenges and national policies. Brussels: EACEA, European Commission.

Fan, X., and Chen, M. (2001). Parental involvement and students' academic achievement: A meta-analysis. Educational Psychology Review, 13(1), 1-22. https:// doi.org/10.1023/A:1009048817385.

Fraenkel, J. R., Wallen, N. E., and Hyun, H. H. (2012). How to design and evaluate research in education (8th Ed.). New York: McGraw Hill.

Gönülalan, G. D. (2019). Ortaokul öğrencilerinde öz yeterlik ve narsisizm. (Yayımlanmamış yüksek lisans tezi). Sakarya Üniversitesi, Sakarya.

Hacısalihoğlu-Karadeniz, M, Aksu, H. H. ve Topal, T. (2012). Aile katılım sürecinin ilköğretim birinci kademe öğrencilerinin matematik başarısına yansımaları. Milli Eğitim Dergisi, 196, 232-245.

Hu, L., and Bentler, P. M. (1999). Cutoff criteria for fit indexes in covariance structure analysis: conventional criteria versus new alternatives. Structural Equation Modeling, 6(1), 1-55. https:// doi.org/10.1080/10705519909540118.

Hunt, J. H., and Hu, B. Y. (2011). Theoretical factors affecting parental roles in children's mathematical learning in American and Chinese-born mothers. The School Community Journal, 21(2), 119-142.

Johnson, E. J., and Descartes, C. H. (2016). Parental influence on academic achievement among the primary school students in Trinidad. Early Child Development and Care, 187(7), 1221-1227. https:/ / doi.org/10.1080/03004430.2016.1163549.

Karabay, E. (2013). Aile ve okul özelliklerinin PISA okuma becerileri, matematik ve fen okuryazarlı̆̆ın yordama gücünün yıllara göre incelenmesi. (Yayımlanmamış yüksek lisans tezi). Gazi Üniversitesi, Ankara.

Karaca, F. (2018). Sekizinci sınıföğrencilerinin TIMSS matematik başarılarının bazı değişkenler açısından incelenmesi: Eskişehir ili örneği. (Yayımlanmamış yüksek lisans tezi). Eskişehir Osmangazi Üniversitesi, Eskişehir.

Karakuş, Ç. (2017). Lise öğrencilerinde psikolojik savunmalar açısından narsisizm ve benlik saygısının karşılaştırılması. (Yayımlanmamış yüksek lisans tezi). İstanbul Sabahattin Zaim Üniversitesi, İstanbul.

Karasar, N. (2019). Bilimsel irade algı çerçevesi ile bilimsel araştırma yöntemi: Kavramlar, ilkeler, teknikler (34. Bask1). Ankara: Nobel Akademik Yayınc1lık.

Khine, M. S. (2013). Application of structural equation modeling in educational research and practice. New York: Springer.

Kleanthous, I., and Williams, J. (2013). Perceived parental influence and students' dispositions to study mathematically-demanding courses in higher education. Research in Mathematics Education, 15(1), 50-69. https:// doi.org/10.1080/14794802.2013.763608. 
Kline, R. B. (2005). Structural equation modeling (2nd Ed.). New York: Guilford Press. Kohut, H. (1984). How does analysis cure? Chicago: University of Chicago Press.

Kotaman, H. (2008). Türk ana babalarının çocuklarının eğitim öğretimlerine katılım düzeyleri. Uludă̆ Üniversitesi Eğitim Fakültesi Dergisi, XXI(1), 135-149.

Lam, B. T., and Ducreux, E. (2013). Parental influence and academic achievement among middle school students: Parent perspective. Journal of Human Behavior in the Social Environment, 23(5), 579-590. https:// doi.org/10.1080/10911359.2013.765823.

Levy, K. N., Ellison, W. D., and Reynoso, J. S. (2011). A historical review of narcissism and narcissistic personality. In W. K. Campbell \& J. D. Miller (Eds.), The handbook of narcissism and narcissistic personality disorder: Theoretical approaches, empirical findings, and treatments (pp. 3-13). John Wiley, Sons Inc.

Ma, X. (2001). Participation in advanced mathematics: Do expectation and influence of students, peers, teachers, and parents matter? Contemporary Educational Psychology, 26(1), 132-146. https:/ / doi.org/10.1006/ceps.2000.1050.

Milli Eğitim Bakanlığı (MEB) (2014). Uluslararası matematik ve fen eğilimleri araştırması. TIMMS 2011 ulusal matematik ve fen raporu 8. sinıflar. Ankara: YEĞİTEK. http:/ / timss.meb.gov.tr/ adresinden edinilmiştir.

Milli Eğitim Bakanlığı (MEB) (2015). PISA uluslararası öğrenci değerlendirme programı. PISA 2012 araştırması ulusal nihai raporu. Ankara: ÖDSGM. http:/ / pisa.meb.gov.tr/ adresinden edinilmiştir.

Milli Eğitim Bakanlı̆̆ı (MEB) (2016). Uluslararası matematik ve fen eğilimleri araştırması. TIMMS 2015 ulusal matematik ve fen ön raporu 4. ve 8. sinıflar. Ankara: ÖDSGM. http:/ / timss.meb.gov.tr/ adresinden edinilmiştir.

Millî Eğitim Bakanlığı (MEB) (2018a). Güçlü yarınlar için 2023 eğitim vizyonu. Ankara: MEB. http:/ / 2023vizyonu.meb.gov.tr/adresinden edinilmiştir.

Milli Eğitim Bakanlığı (MEB) (2018b). Matematik dersi öğretim programı (İlkokul ve ortaokul 1, 2, 3, 4, 5, 6, 7 ve 8. sinıflar). Ankara: Talim Terbiye Kurulu Başkanlığ1.

Milli Eğitim Bakanlığı (MEB) (2019). PISA 2018 Türkiye ön raporu. Ankara: Eğitim Analiz ve Değerlendirme Raporları Serisi. http:/ / pisa.meb.gov.tr/ adresinden edinilmiştir.

Mullis, I. V. S., Martin M. O., Foy, P., and Arora, A. (2012). TIMSS 2011 international results in mathematics. Chestnut Hill, MA, USA: TIMMS \& PIRLS International Study Center, Lynch School of Education, Boston College and Amsterdam, Netherlands: Internaional Assocation for the Evaluation (IAE).

National Council of Teachers of Mathematics (NCTM) (2014). Principles to actions: Ensuring mathematical success for all. Reston, VA: NCTM.

National Research Council (NRC) (2012). Education for life and work: Developing transferable knowledge and skills in the 21st century. Committee on Defining Deeper Learning and 21st Century Skills, J. W. Pellegrino and M. L. Hilton, Editors. Board on Testing and Assessment and Board on Science Education, Division of Behavioral and Social Sciences and Education. Washington, DC: The National Academies Press.

Organisation for Economic Co-Operation and Development (OECD) (2016). PISA 2015 results in focus. Paris. http:/ / www.oecd.org/ pisa/ adresinden edinilmiştir. 
Özer, Y. ve Anıl, D. (2011). Öğrencilerin fen ve matematik başarılarını etkileyen faktörlerin yapısal eşitlik modeli ile incelenmesi. Hacettepe Üniversitesi Ĕ̆itim Fakültesi Dergisi, 41, 313-324.

Özgen, K. ve Bindak, R. (2011). Lise öğrencilerinin matematik okuryazarlı̆̆ına yönelik öz-yeterlik inançlarının belirlenmesi. Kuram ve Uygulamada Ĕ̆itim Bilimleri, 11(2), 1073-1089.

Özözen-Danacı, M. (2017). Üniversite öğrencilerinin çocuk narsisizmi ile çocukluk dönemi mutluluk ve huzur anıları arasındaki ilişki. Uluslararası Eğitim Bilimleri Dergisi, 4(12), 13-25. https:/ / doi.org/10.16991/INESJOURNAL.1484.

Öztürk, D. (2016). Öğretmen ve aile desteği, motivasyon ve ortaokul öğrencilerinin matematik başarısı: Motivasyonun aracı rolü. (Yayımlanmamış yüksek lisans tezi). Abant İzzet Baysal Üniversitesi, Bolu.

Papanastasiou, C. (2000). Effects of attitudes and beliefs on mathematics achievement. Studies in Educational Evaluation, 26(1), 27-42. https:// doi.org/10.1016/S0191-491X(00)00004-3.

Peker, C. (2015). Ergenlerde algılanan ebeveynlik stilleri, narsisizm, psikolojik ve sosyal uyum. (Yayımlanmamış yüksek lisans tezi). Mersin Üniversitesi, Mersin.

Provasnik, S., Malley, L., Stephens, M., Landeros, K., Perkins, R., and Tang, J. H. (2016). Highlights from TIMSS and TIMSS advanced 2015: Mathematics and science achievement of U.S. Students in grades 4 and 8 and in advanced courses at the end of high school in an international context. U. S. Department of Education, National Center for Education Statistic. Washington, DC. http:/ / nces.ed.gov adresinden edinilmiştir.

Régner, I., Loose, F., and Dumas, F. (2009). Students' perceptions of parental and teacher academic involvement: Consequences on achievement goals. European Journal of Psychology of Education, 24(2), 263-277. https:/ / doi.org/10.1007/BF03173016.

Rhodewalt, F., and Morf, C. C. (1998). On self-aggrandizement and anger: A temporal analysis of narcissism and affective reactions to success and failure. Journal of Personality and Social Psychology, 74(3), 672-685. https:/ / doi.org/10.1037/0022-3514.74.3.672.

Sarıkaya, M. (2019). Ortaokul 7. sinıföğrencilerinin fen bilimleri dersi kuvvet ve enerji ünitesindeki kavram öğrenmeleri üzerine aile katkısının incelenmesi. (Yayımlanmamış yüksek lisans tezi). Erciyes Üniversitesi, Kayseri.

Savaş, E., Taş, S. ve Duru, A. (2010). Matematikte öğrenci başarısını etkileyen faktörler. İnönü Üniversitesi Eğitim Fakültesi Dergisi, 11(1), 113-132.

Schleicher, A. (2018). PISA 2018 insights and interpretations. Paris: OECD Publishing. https:/ / www.oecd.org adresinden edinilmiştir.

Soni, A., and Kumari, S. (2015). The role of parental math attitude in their children math achievement. International Journal of Applied Sociology, 5(4),159-163. https://doi.org/10.1007/s10763-015-9687-5.

Şeker, H. ve Gençdoğan, B. (2006). Psikolojide ve eğitimde ölçme aracı geliştirme. Ankara: Nobel Yayın Dağıtım.

Şentürk, M. (2019). Aile faktörünün ilkokul öğrencilerinin akademik başarılarına etkisinin incelenmesi. (Yayımlanmamış yüksek lisans tezi). Çanakkale Onsekiz Mart Üniversitesi, Çanakkale. 
TEDMEM. (2014). PISA 2012: Türkiye üzerine değerlendirmeler ve öneriler (TEDMEM Analiz Dizisi 2). Ankara: Türk Eğitim Derneği.

Thomaes, S., Stegge, H., Bushman, B. J., Olthof, T., and Denissen, J. (2008). Development and validation of the Childhood Narcissism Scale. Journal of Personality Assessment, 90(4), 382-391. https:/ / doi.org/10.1080/00223890802108162.

Usta, H. G. (2014). PISA 2003 ve PISA 2012 matematik okuryazarlı̆̆ı üzerine uluslararası bir karşılaştırma: Türkiye ve Finlandiya. (Yayımlanmamış doktora tezi). Ankara Üniversitesi, Ankara.

Uysal, E. ve Yenilmez, K. (2011). Sekizinci sınıf öğrencilerinin matematik okuryazarlığı düzeyi. Eskişehir Osmangazi Üniversitesi Sosyal Bilimler Dergisi, 12(2), 1-15.

Yiğit, T. (2019). Bireyin aile değerlendirme düzeyi ile problem çözme becerisi arasındaki ilişki. (Yayımlanmamış yüksek lisans tezi). İstanbul Ticaret Üniversitesi, İstanbul.

\section{Summary}

\section{Introduction}

The importance of skills such as problem-solving, critical thinking, reasoning skill, self-efficacy, which are referred to as 21st-century skills, especially because of the rise of technology, is gradually increasing (NRC, 2012). Therefore, raising the generations with the knowledge and skills appropriate to the the age is indispensable for the social, economic, and cultural progress of the countries (MNE, 2016). Because increasing individual success is accepted as a prerequisite for social success (Eurydice, 2011), many developed and developing countries have changed the dynamics of education policies and opened a door to a series of educational approaches that consider individual developments (NCTM, 2014). Our country's education system has also made strong steps to change its educational needs and goals, and has made the understanding of raising individuals with knowledge, skills, and behaviors integrated with competencies into the focus of its educational philosophy (MNE, 2018a). Despite all these positive developments, the success level of students in many countries is far below the desired level (Mullis et al., 2012; OECD, 2016; Prosvanik et al., 2016). However, the most important factor that directs countries to develop their targets is individuals. Therefore, it is very precious to know the factor groups that affect students' learning and to conduct studies in this direction.

\section{Method}

In the study, in which the perceived parental support levels on middle school students' learning of mathematics were examined according to narcissism, gender, grade level, mathematics success, number of siblings, and education level of parents the screening model was used. In this model, by following the method, the subject, individual or object, which is the subject of the research, is tried to be defined in its conditions and as it is, without touching the nature of the sample (Karasar, 2019). The research was carried out with a total of 544 students studying at the $6^{\text {th }}, 7^{\text {th }}$, and $8^{\text {th }}$ grade-levels of a public middle school in the city center. Perceived Parental Support and Childhood 
Narcissism scales were used as data collection tools in the research. In the research in which the relational scanning model was adopted, the Pearson product-moment correlation coefficient, t-test, and one-way analysis of variance were used in addition to descriptive statistical techniques.

\section{Results}

Findings indicate that there is a positive relationship between students' learning mathematics, parent encouragement, father's attitudes and help, mother's attitudes and help, parent achievement expectation and narcissism levels. In another finding obtained from the study, it was determined that the perceived parental effects on students' mathematics learning did not differ according to the gender variable. These findings confirm the effects of parents, which are among the main factors in the formation of narcissism in individuals. In this context, it can be said that perceived parental influence does not discriminate gender on their children's mathematics learning. Another finding reached from the research was obtained from the perceived parental effects on students' mathematics learning according to their grade levels. According to the findings, father's attitudes and help in terms of perceived parental effects are significant in favor of the lower grade level. Therefore, the effect of a father on their child's learning of mathematics is felt more than other parent's effects according to their class levels. Another finding of the research is that parent encouragement is found significant in students' mathematics success. According to this finding, parental encouragement takes an important place in the increase of students' mathematics success. In the other findings obtained from the study, it was determined that as the number of siblings increased, the perceived support of the parents, father's attitudes and help, and mother's attitudes and help decreased. Significant relationships were found between parent encouragement and mathematics success, a number of siblings and level of father education; between father's attitudes and help, and the level of the class, the number of siblings, and the level of education of parents; between mother's attitudes and help, and the number of siblings, and the education level of the mother and father.

\section{Discussion}

As a result, parental support has undeniable importance for our children to be good math learners. In the learning processes of children, all stakeholders should be aware of and fulfill their responsibilities. In particular the education of parents is as necessary and important as the education of our children to ensure the continuity of parental support. The fact that parents have the necessary knowledge and skills concerns not only their children but also the whole society. In this respect, parents should value their children's efforts to avoid having a narcissistic effect on their child's learning of mathematics, preventing them from showing selfless reflexes. In this respect, mothers and fathers should be aware of their children's mathematics efforts and behave by their mathematic development. Relationships between child and parent also shape their perspectives on lessons. The fact that parents support their children's mathematical knowledge and skills contribute to their perception of mathematics more easily in the upcoming years. Therefore, parents should value their children's learning wishes. 
Therefore parents should help their children learn math regardless of their learning level or age range.

\section{Araştırmanın Etik İzinleri}

Yapılan bu çalışmada "Yükseköğretim Kurumları Bilimsel Araştırma ve Yayın Etiği Yönergesi" kapsamında uyulması belirtilen tüm kurallara uyulmuştur. Yönergenin ikinci bölümü olan "Bilimsel Araştırma ve Yayın Etiğine Aykırı Eylemler" başlı̆̆ altında belirtilen eylemlerden hiçbiri gerçekleştirilmemiştir.

Etik kurul izin bilgileri

Etik değerlendirmeyi yapan kurul adı = T.C. İzmir Valiliği İl Milli Eğitim Müdürlüğü Etik değerlendirme kararının tarihi $=11.02 .2020$

Etik değerlendirme belgesi sayı numarası = 12018877-604.01.02-E.3049389

\section{Yazar Bilgileri/Authors' Biodata}

Deniz KAYA lisans eğitimini Dokuz Eylül Üniversitesi Buca Eğitim Fakültesi Fen Bilimleri öğretmenliği alanında almıştır. Yüksek lisans ve doktora eğitimini ise Dokuz Eylül Üniversitesi Eğitim Bilimleri Enstitüsü İlköğretim Matematik Eğitimi alanında tamamlamıştır. Halen Milli Eğitim Bakanlığında öğretmen olarak görev yapmaktadır.

Deniz Kaya received his BA in Science Teaching at Dokuz Eylül University Buca Faculty of Education, and MA and PhD in Department of Elementary Mathematics Education at Dokuz Eylül University Graduate Institute of Educational Sciences. He is still working as a teacher at the Ministry of National Education. 